Año LXXXII. urtea $279-2021$ Enero-abril Urtarrila-apirila

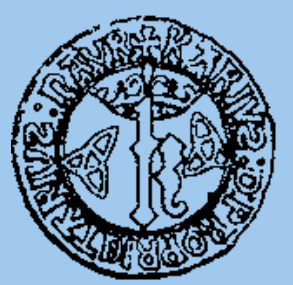

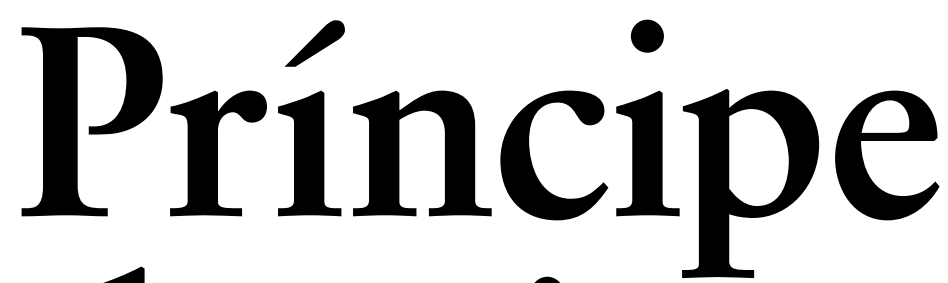

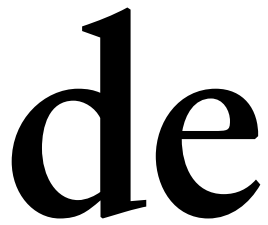
Viai

SEPARATA

\title{
La huella de la Inquisición en la Biblioteca de Navarra
}

Roberto SAN MARTÍN CASI 


\section{Sumario / Aurkibidea}

\section{Príncipe de Viana}

Año LXXXII • n. ${ }^{\circ} 279$ - enero-abril de 2021

LXXXII. urtea $\cdot 279$. zk. 2021 ko urtarrila-apirila

\section{GUSTAV HENNINGSEN / MARISA REY-HENNINGSEN}

\section{Homenaje / Omenaldia}

Ignacio Panizo (coord./koord.)

Vol. II. lib.

\section{ESTUDIOS DE INVESTIGACIÓN EN HOMENAJE \\ A GUSTAV HENNINGSEN Y MARISA REY-HENNINGSEN / \\ IKERKETA LANAK, GUSTAV HENNINGSENEN \\ ETA MARISA REY-HENNINGSENEN OMENEZKOAK}

Entre impostores anda el juego en el Siglo de Oro. Dos vizcaínos ante la Inquisición y unos conversos toledanos próximos a Garibay

Un formulario de la Secretaría de Aragón del Consejo de la Inquisición (BC, ms. 2168)

Anna Gudayol

Las cartillas editadas en Estella e incautadas en Medellín por la Inquisición (1561)

Javier Itúrbide Díaz

El Tribunal de Navarra y sus funcionarios inquisitoriales:

algunas observaciones

Consuelo Juanto Jiménez

Goya investigado por la Inquisición: la censura de los Caprichos en 1804

$\mathrm{El}$ «Informe del inquisidor Avellaneda» sobre las complicidades brujeriles en los valles centrales y orientales del Pirineo navarro José M. Floristán Imízcoz, Jesús Moya Mangas 


\section{Sumario / Aurkibidea}

La Inquisición en Tudela durante los siglos XVI y XVII:

presencia e incidencia social

Iñigo Pérez Ochoa

La huella de la Inquisición en la Biblioteca de Navarra

Roberto San Martín Casi

Los memoriales como fuente para el estudio de la Inquisición

en el Tribunal de Navarra (1609-1621)

Bárbara Santiago Medina

De comisarios, confesores y vecinos: la proyección de la Inquisición

a finales del Antiguo Régimen

Marina Torres Arce

Los niños como víctimas y los niños como verdugos en la caza de brujas:

Navarra, siglo XVI

Jesús M. Usunáriz

Volver a las relaciones de causas. El ejemplo de los berberiscos

del reino de Granada

Bernard Vincent

\section{LOS TRABAJOS Y LOS DÍAS DEL AÑO 2020 / 2020ko LANAK ETA EGUNAK}

Tesis doctorales sobre temática navarra de ciencias humanas, sociales y jurídicas, leídas en 2020

(Según la Base de datos Teseo del Ministerio de Educación)

Narrativa de autores navarros en castellano, año 2020

Mikel Zuza Viniegra

Euskarazko literaturak 2020an zer?

Ángel Erro Jiménez

Donación del fondo bibliográfico y documental Gustav Henningsen y Marisa

Rey a la Universidad Pública de Navarra

Iñaki Montoya Ortigosa

Formación en Archivística y Gestión Documental en la Universidad de Navarra

Yolanda Cagigas Ocejo

6 Príncipe de Viana (PV), 279, urtarrila-apirila, 2021

ISSN: 0032-8472 | ISSN-e: 2530-5824 | ISSN-L: 0032-8472

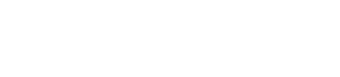




\section{Sumario / Aurkibidea}

Apuntes sobre etnografía, folclore y cultura tradicional David Mariezkurrena Iturmendi

El alivio y reparo. La forma audiovisual

Marga Gutiérrez Díez

Proceso de decantación. Exponer en 2020

Mireya Martín Larumbe

Exposición «Maleficium. Navarra y la caza de brujas. Siglos XIV-XVII»

(Archivo Real y General de Navarra, julio-diciembre, 2020)

Jesús M. Usunáriz

Carlos Cánovas

Alicia Ezker Calvo

Discurso Premio Príncipe de Viana 2020

Carlos Cánovas Ciaurriz

Currículums

Analytic Summary

Normas para la presentación de originales / Idazlanak aurkezteko arauak /

Rules for the submission of originals 


\section{La huella de la Inquisición en la Biblioteca de Navarra}

\section{Inkisizioaren aztarna Nafarroako Liburutegian}

The trace of the Inquisition in the Library of Navarre

Roberto San Martín Casi

Biblioteca de Navarra

robersmc@gmail.com

https://orcid.org/0000-0001-6156-0755

DOI: https://doi.org/10.35462/pv.279.8 


\section{RESUMEN}

La presencia de la Inquisición en el fondo bibliográfico antiguo de la Biblioteca de $\mathrm{Na}$ varra permite analizar la influencia de la acción y control ideológico del Santo Oficio en la Edad Moderna. Es un trabajo empírico, cuantitativo, basado en la localización de ejemplares expurgados. Se expone una selección de autores, obras, cronologías, lugares de publicación, materias censuradas, índices inquisitoriales más utilizados, métodos de censura aplicados, las procedencias de los ejemplares y la identificación de los censores firmantes. Así también, los ejemplares de obras incluidas en los índices que nunca fueron revisados y la existencia de unos pocos libros prohibidos.

Palabras clave: libros expurgados; Inquisición; Biblioteca de Navarra.

\section{LABURPENA}

Inkisizioak Nafarroako Liburutegiaren funts bibliografiko zaharrean duen presentziari esker, posible da aztertzea Ofizio Santuaren jardun eta kontrol ideologikoak Aro Modernoan izan zuen eragina. Lan enpiriko eta kuantitatiboa da, zentsuratutako aleak aurkitzean datzana. Hainbat gauza lantzen dira: autoreak, obrak, kronologiak, argitalpen-lekuak, zentsuratutako gaiak, inkisizio-indizerik erabilienak, aplikatutako zentsura-metodoak, aleen jatorria eta sinatzen duten zentsuratzaileen identifikazioa. Horiez gain, indizeetan sartutako obren aleak, inoiz miatu ez zirenak, eta liburu debekatu gutxi batzuk.

Gako hitzak: zentsuratutako liburuak; Inkisizioa; Nafarroako Liburutegia.

\section{ABSTRACT}

The presence of the Inquisition in the old bibliographic collection of the Library of Navarra allows us to analyze the influence of the action and ideological control that the Holy Office exercised throughout the Modern Age. It is an empirical, quantitative work, based on the location of expurgated copies. It presents a selection of authors, works, chronologies, places of publication, censored subjects, the most commonly used inquisitorial indexes, the censorship methods applied, the origins of the copies and the identification of the signing censors. Also, the copies of books included in the Indexes that were never reviewed and the existence of a few banned books.

Keywords: Expurgated books; Inquisition; Library of Navarre. 


\begin{abstract}
1. INTRODUCCIÓN. 2. LA CENSURA DE LIBROS POR LA INQUISICIÓN. 2.1. Índices de libros prohibidos y expurgados. 2.2. Los responsables de la censura. 3. El FONDO ANTIGUO DE LA BIBLIOTECA DE NAVARRA. 4. LIBROS RELACIONADOS CON LA INQUISICIÓN. 5. LIBROS EXPURGADOS. 5.1. Autores, obras y ejemplares. 5.2. Índices más mencionados y cronología de los expurgos. 5.3. Modalidades de revisión y expurgo. 5.4. Procedencia de los ejemplares expurgados. 5.5. Los censores: calificadores, comisarios y comisionados. 6. EJEMPLARES NO EXPURGADOS. 6.1. Autores, obras y ejemplares. 6.2. Cronología y lugares de impresión. 6.3. Materias y temas. 6.4. Procedencia. 7. LIBROS PROHIBIDOS. 7.1. Autores, obras y ejemplares. 7.2. Cronología, inclusión en los índices y lugares de impresión. 7.3. Materias y temas. 7.4. Procedencia. 8. CONSIDERACIONES FINALES. 9. LISTA DE REFERENCIAS.
\end{abstract}

\title{
1. INTRODUCCIÓN
}

Durante más de trescientos años, una institución como el Santo Oficio de la Inquisición, defensora de la ortodoxia católica, del orden político y social establecido, condicionará, mediante múltiples procedimientos de control, la transmisión de ideas en el orbe hispano. Intervendrá poderosamente en el mundo del libro y la lectura, a través de la publicación de edictos e índices de libros prohibidos y expurgados, en la vigilancia de las fronteras, la inspección de librerías y bibliotecas y el fomento de las delaciones particulares.

En estas páginas se pretende dar a conocer la aplicación e incidencia de su actividad censoria en el conjunto del fondo antiguo de la Biblioteca de Navarra. Esta biblioteca alberga una colección de libros publicados entre los siglos XV y el primer tercio del siglo XIX considerable, cerca de catorce mil volúmenes. Este es un trabajo empírico, cuantitativo, basado en la localización de ejemplares en los que la maquinaria inquisitorial dejó su huella -expurgos-, así como de los que escaparon a su control. También se mencionan los libros y otros impresos menores que existen en la Biblioteca de y sobre la Inquisición, publicados durante el periodo de su existencia. Aunque el artículo se centra en aportar datos, estos perderían valor sin una contextualización histórica basada en los numerosos estudios sobre la censura inquisitorial. De igual modo, es necesario reseñar la procedencia de esta colección bibliográfica.

El núcleo del artículo se centra en los 476 ejemplares expurgados que se han detectado. Se expone una selección de autores, destacando los considerados de primera clase -condenados por herejes o sospechosos de serlo-, las obras con más ejemplares 
expurgados, la exhaustividad de estos expurgos, las examinadas en más de una ocasión, las cronologías y lugares de impresión, así como las materias más frecuentes. También se destacan los índices de libros prohibidos y expurgados más utilizados y la correlación entre las fechas de edición, su aparición en los índices y su efectivo expurgo; los métodos de censura encontrados; las procedencias de los ejemplares y la identificación de los censores firmantes.

En un plano secundario se muestra los ejemplares de obras incluidas en los índices que por diversos motivos nunca fueron revisados. De igual modo, también la presencia de unos pocos libros prohibidos. En ambos casos, junto con los datos, se indican títulos, autores, cronologías, procedencias, etc.

\section{LA CENSURA DE LIBROS POR LA INQUISICIÓN}

Desde el último tercio del siglo XX se ha producido una eclosión de estudios sobre la Inquisición. La censura inquisitorial, actividad de primer orden de la institución al menos desde mediados del siglo XVI, es un tema recurrente en toda esta bibliografía. Martínez de Bujanda, en su obra sobre El índice de libros probibidos y expurgados de la Inquisición española (1551-1819), dedica diez páginas a listar una bibliografía selecta exclusivamente sobre esta censura (2016, XXI-XXX). Sin embargo, son escasas las investigaciones dedicadas a su aplicación concreta, esto es, a la ingente tarea de expurgación de libros en bibliotecas, que supone una fuente de información fundamental, aunque no única, para conocer la incidencia real de la acción censoria ${ }^{1}$.

Hace tres décadas, Pardo Tomás (1991, p. 334) señalaba las deficiencias en este aspecto y, en estos años son escasos los estudios publicados sobre libros censurados en bibliotecas. Quizá, la dificultad de examinar los miles de libros antiguos que albergan las bibliotecas españolas haya frenado esta investigación. Con ser pocos, son más los trabajos referidos a las colecciones de personajes de la nobleza, cargos inquisitoriales, requisas de libros, o de la propia biblioteca del Consejo de la Suprema Inquisición, que los centrados en bibliotecas herederas de los fondos bibliográficos desamortizados. Por señalar algunos trabajos, destacan las tesis de Galindo, Libros expurgados de la Biblioteca Histórica de Santa Cruz de Valladolid (2015), y de Sánchez Herrador, La Biblioteca del Colegio de La Encarnación de los jesuitas de Montilla (2016). Así como artículos referidos a las bibliotecas de la universidad de Oñati (Luzuriaga, 2008), la de los jesuitas de Loyola (Iturriaga, 1992), los libros prohibidos del colegio de los jesuitas de Pamplona (Vergara, 2006), del colegio franciscano de la Santa Cruz de Querétaro en México (García Aguilar, 2019), la colección de incunables expurgados de la universidad de Valencia (Barberá, 2014), o de bibliotecas militares como las de los Guardia Marinas (García-Molina, 2006) y la del colegio de Artillería de Segovia (Navarro, 2017).

1 Junto a la acción expurgatoria en bibliotecas, en la práctica de la censura inquisitorial también fueron determinantes, aunque con desigual efectividad, los controles en los puertos a la entrada de libros extranjeros (Galende \& Santiago, 2007, pp. 73-75), las inspecciones a librerías (Pinto, 1989, pp. 184-186), etc. 
Es sabido que el Tribunal del Santo Oficio de la Inquisición fue creado en 1478, a iniciativa de los Reyes Católicos, para salvaguardar la unidad de la fe cristiana mediante la represión y sometimiento de las minorías disidentes. Aunque era una institución eclesiástica, estaba tutelada por la Corona y formaba parte de la estructura polisinodial de Consejos de la monarquía española. Desde sus inicios, el control y censura de textos fue considerado un asunto de Estado. Los libros constituían el vehículo ideal para la difusión de corrientes de pensamiento consideradas peligrosas o condenables. La amenaza protestante, unida a la extraordinaria difusión del libro gracias a la imprenta, activó todas las alarmas en los países católicos.

En 1558 se promulga una pragmática que impone un severo control a todo el circuito comercial del libro. Se reafirma la censura preventiva instituida ya en 1502, que desde 1554 era competencia exclusiva del Consejo Real de Castilla, y una censura represiva, a posteriori, una vez publicada la obra, competencia exclusiva del Santo Oficio. Se regula la importación y el comercio de libros, la censura de libros ya impresos, y la inspección de librerías y bibliotecas. Se prohíbe importar, tener o vender cualquier libro que estuviese prohibido por el Santo Oficio (Reyes, 2000, 1, pp. 197-200). Felipe II impuso un estado confesional católico, custodiado por la Inquisición, que estará vigente con ligeras modificaciones hasta las postrimerías del Antiguo Régimen (Bombín, 1997, p. 16). En el ámbito intelectual, la Inquisición monopolizará la censura represiva con la facultad de fijar unos principios generales que facilitarán la delación de determinadas obras y la condenación de autores y títulos concretos.

\section{1. Índices de libros prohibidos y expurgados}

La publicación de edictos y catálogos de libros prohibidos o expurgados constituirá uno de los principales instrumentos que utilizará el Santo Oficio en su defensa de la integridad católica. Desde mediados del siglo XVI hasta su desaparición, publicó nueve índices -1551, 1559, 1583-1584, 1612, 1640, 1707, 1747 y 1790-, a los que hay que añadir dos apéndices $-1614,1628-$, dos suplementos $-1739,1805-$ y numerosos edictos en los intervalos, el último en 1819. Entre autores y obras prohibidas o expurgadas sobrepasan las ocho mil referencias (Martínez de Bujanda, 2016, pp. 244-245).

El espacio cronológico que hay entre los consecutivos índices es un reflejo de la propia evolución de la institución. Se comprueba una primera etapa de desarrollo y plenitud que llega hasta mediados del siglo XVII, en la que se editan seis de los nueve índices, y una segunda etapa de progresiva decadencia, que se evidencia en el largo paréntesis entre el índice de 1640 y el siguiente de 1707 . Sin duda, esta periodización encubre fluctuaciones, fases de mayor vitalidad con otras más apáticas, condicionadas por las cambiantes circunstancias políticas y los problemas organizativos de la propia Inquisición (Peña, 2004, p. 807; Pinto, 1983, p. 110). Los índices irán evolucionando a merced de las coyunturas históricas, de un arma para combatir el peligro protestante, a un instrumento de la Contrarreforma que extiende la censura más allá de los asuntos religiosos en el siglo XVII, al combate del jansenismo y de la filosofía de las Luces en el siglo XVIII, hasta convertirse en un baluarte contra las ideas liberales en su fase final. 
Los dos primeros índices se publicaron en 1551 y 1559, siendo inquisidor general Fernando de Valdés, solo incluyen libros prohibidos. Responden a una situación de crisis del imperio español, tras la consolidación de la Reforma en territorios europeos, en el que se intensifica la política de cierre ideológico para evitar el contagio luterano. En estos años destaca la gran preocupación por las ediciones de las biblias, debido al uso y significado dado por los reformadores, que culminará en la Censura General de Biblias (1554). El índice de 1559 marcará las directrices temáticas de los siguientes índices. Además de las ediciones y comentarios de textos bíblicos, destacan las obras de los Padres de la Iglesia y autores clásicos comentados por heréticos, escritos científicos de autores reformados, libros de ciencias ocultas, textos críticos con la jerarquía eclesiástica, etc. De los libros en romance, se hace especial hincapié en textos de humanistas -principalmente de Erasmo-, obras de controversia entre católicos y herejes que indirectamente difundían sus ideas, de espiritualidad, devocionarios, catecismos y oraciones propias de la piedad popular, discordantes con la ortodoxia.

Un severo control preside el período que sigue al índice de 1559, suscitando una inevitable inseguridad y descontento en los ambientes intelectuales y libreros hispanos. Los primeros, por las dificultades para acceder a ciertas obras de temática no religiosa, lo segundos, por las pérdidas económicas provocadas por las requisas de libros (Martínez de Bujanda, 2016, p. 68; Peña, 2015, pp. 47-48). En 1583-1584 se publica un nuevo índice, durante el mandato del inquisidor general Gaspar de Quiroga. Comprende dos catálogos, uno de libros prohibidos (1583), y, por primera vez, otro de expurgados (1584). Toma como modelo al Índice tridentino (Roma, 1564) y fija catorce reglas generales, que se convierten en los principios que regirán, con ligeras modificaciones y adiciones, la censura inquisitorial hasta el último índice. Establece la distinción entre «heresiarcas», fundadores e ideólogos de herejías cuyas obras son prohibidas en su totalidad, de los "heréticos», de quienes se autoriza, previo expurgo, algunas obras no religiosas, así como las traducciones y ediciones de los Padres de la Iglesia o de los clásicos. Dispone que los escritos de autores católicos que contienen asertos falsos o escandalosos, sean permitidos una vez expurgados. La aplicación de las reglas, además de preceptivas, sirvió de orientación a los calificadores, comisarios o a cualquier persona, para poder denunciar un libro cuyo contenido les pareciera susceptible de condena o censura. Esta posibilidad generó un ambiente de desconfianza entorno al libro, incluso de autocensura en muchos escritores (Pardo, 1991, p. 186; Pérez, 2002, pp. 408-416).

En 1612, ordenado por el inquisidor general Bernardo de Sandoval, se publica un nuevo índice que recoge en un solo volumen, dividido en dos secciones, los libros prohibidos y expurgados. La nómina de autores condenados, libros prohibidos o expurgados crece de forma exponencial. Introduce algunas novedades. Al igual que los índices romanos, divide los autores y obras en tres clases. La primera incluye a los autores herejes o sospechosos de herejía de los que solo se permiten, previo expurgo, obras que no tratan de religión y sean «útiles». La segunda se refiere a los libros de autores católicos con obras prohibidas o expurgadas. La tercera recoge los libros anónimos que contienen ideas contrarias a la ortodoxia católica. Otra novedad es la normativa expresa destinada a los libreros, importadores de libros e impresores. Los libreros, además de disponer de un ejemplar del catálogo, debían llevar un inventario de los libros que 
poseen y presentarlo ante los requerimientos inquisitoriales. Los importadores declarar a los comisarios de aduanas los libros que traen del extranjero. Por último, entre los temas prohibidos incluye las obras con pasajes obscenos que atentan la moral cristiana y mezclan herejías o errores de la fe (Martínez de Bujanda, 2016, p. 94).

La aplicación del catálogo se reveló una tarea ardua a causa del gran número de libros que debían ser examinados y corregidos en un plazo limitado. En 1614 se edita un apéndice que incluye nuevas obras e introduce ciertas precisiones. Prescribe que se añada la nota "Auctor damnatus, versio permisa» [Autor condenado, edición autorizada], en los expurgos de obras de autores de primera clase. Que se entienda como prohibidas hasta su expurgación, las obras que en el índice lleven la nota «Donec expurgatur» [Hasta que se expurgue]. Para agilizar las tareas de expurgo, posibilita la colaboración externa de personas con formación teológica, miembros de conventos, universidades, etc., para revisar las bibliotecas de sus instituciones conforme al índice. En 1628 aparece un segundo apéndice que recoge los edictos promulgados desde 1614 con nuevas prohibiciones.

La nueva edición del índice vio la luz en 1632, promovido por el inquisidor general Antonio Zapata. Al poco de su aparición, llegaron a la Suprema quejas relativas a sus numerosos errores formales y de contenido. La llegada de Antonio de Sotomayor a la dirección de la Inquisición coincide con la decisión de revisar el catálogo. Todo lo cual provocó su escasa utilización en labores de censura (Martínez de Bujanda, 2016, pp. 129-134, 139-144).

Con ocho años de intervalo, en 1640 se publica el nuevo índice. En realidad, es una versión corregida del anterior, más preciso en la identificación de autores y obras, pero con pocas condenaciones y expurgaciones nuevas. Amplía las reglas generales a dieciséis, desglosa y matiza las ya enunciadas en los índices de 1583-1584 e intercala una nueva regla sobre el modo de realizar los expurgos. Así también extiende la prohibición absoluta de todo tipo de escritos licenciosos (Martínez de Bujanda, 2016, p. 145). Entre las advertencias que introduce, destaca la aclaración al uso de la nota "Caute lege» [Leer con cautela], aplicada a libros de autores antiguos católicos y de los Padres de la Iglesia, que habían sido editados por herejes.

A la febril actividad censoria hasta la primera mitad del siglo XVII, sigue un largo período -67 años- hasta que aparezca un nuevo índice en 1707 . Pese a las numerosas emisiones de edictos censurando nuevos libros, las dificultades para mantener el control se manifestará de forma recurrente. Los problemas económicos y organizativos por los que atraviesa la institución, estarán en la base del relajamiento y escasa eficacia en las inspecciones a librerías y controles aduaneros (Pardo, 1991, pp. 38, 89-93). Este índice se comenzó a idear en la década de 1660 pero los trabajos no se iniciaron hasta 1679, en tiempos del inquisidor Diego Sarmiento de Valladares (Martínez de Bujanda, 2016, p. 155). El primer tomo se imprimió en 1685, pero se interrumpió la edición por problemas económicos y contratiempos internos. Los trabajos sufrieron dilaciones hasta culminar en 1707 bajo el mandato del inquisidor general Vidal Marín, en plena guerra de Sucesión. Publicado en dos volúmenes, el primero reunía los pliegos impresos en 
1685, más una adenda con lo prohibido y expurgado posteriormente. Cronológicamente pertenece al siglo XVIII, pero en contenidos sigue ligado al XVII, pues la mayor parte de los autores y títulos incorporados se publicaron en la segunda mitad de dicho siglo (Kamen, 1988, p. 342). Incluye obras relacionadas con la religiosidad y devoción popular, impresos menores editados de forma anónima, y unos pocos autores jansenistas, galicanos o novatores españoles. Ante la disminución de los autos de fe y de las herejías, la actividad del Santo Oficio se concentró en el control social del pueblo, vigilando los escritos que pudieran atentar la moral católica y en el peligro que para las instituciones eclesiásticas suponía la renovación del pensamiento en el ámbito europeo.

En los cuarenta años que separan la publicación del siguiente índice, la Inquisición se vio sumida en una progresiva decadencia y pérdida de influencia política y social. En este período sobrevienen once inquisidores generales. Pese a esta inestabilidad, se suceden numerosos edictos, especialmente de obras jansenistas y de literatura popular, que darán lugar en 1739 a la publicación de un «Suplemento» al índice de 1707. En 1747, bajo el mandato del inquisidor Pérez de Prado, se edita un nuevo índice en el que los jesuitas ejercieron un papel preponderante. Son abundantes las condenas a impresos en castellano de religiosidad popular, y se comprueba un notorio aumento de textos en francés. Como apéndice incluye un amplio listado de autores y libros jansenistas prohibidos.

Con la llegada al trono de Carlos III y la expulsión de los jesuitas, la influencia social de la Inquisición se aminora al tiempo que crece su desprestigio en los ambientes ilustrados. En 1768 una cédula real limitará considerablemente su potestad en materia de censura. Acota su competencia a textos de carácter religioso, autoriza a los lectores a corregir ellos mismos los libros a expurgar, y establece la aprobación real antes de publicar nuevos edictos. En 1782, durante el mandato del inquisidor Felipe Bertrán se autoriza la lectura de la Biblia en lenguas vernáculas. El sucesor, Rubín de Ceballos, más rigorista, se limitó a publicar en 1790 un nuevo y último índice que es una reedición del de 1747, completado con los edictos publicados en el ínterin. Aparece en el momento en que la monarquía, acuciada por los acontecimientos de Francia, busca la colaboración de la Inquisición para hacer frente a la propaganda revolucionaria. Para facilitar su manejo, desaparece la distinción de las tres clases de los índices anteriores y los reagrupa en una sola lista alfabética de autores y obras anónimas. La mayoría de los nuevos títulos incluidos son libros en castellano y francés, obras filosóficas y literarias de la Ilustración, literatura popular religiosa y profana y, tras la revolución francesa, los textos que llegan del país vecino propagando ideas contrarias al orden político-social (Martínez de Bujanda, 2016, pp. 169-200).

Hasta la invasión napoleónica, la Inquisición continuó ejerciendo su actividad censoria a través de edictos. Su precaria situación la convirtió en un mero instrumento gubernamental para frenar la penetración de la propaganda revolucionaria. Ante la dispersión de los numerosos edictos promulgados, en 1805 se publica un «Suplemento» al índice de 1790. La guerra de Independencia supuso el fin temporal de toda acción inquisitorial, que culminó en su abolición por las Cortes de Cádiz en 1813. Con la restauración del absolutismo, Fernando VII restablece la Inquisición con sus funciones 
tradicionales. En los años siguientes, sucesivos inquisidores generales publicaron tres edictos de censura, en 1815, 1817 y 1819 . En esta última etapa, aunque seguirá condenando escritos contra la fe y la moralidad pública, su actividad se dirige sobre todo a los aspectos políticos, a la defensa de los valores del Antiguo Régimen. En 1820, al comienzo del Trienio Liberal, la Inquisición fue suprimida. Tres años más tarde, presentes otra vez los absolutistas, el Tribunal volvió a estar rehabilitado, pero prácticamente inactivo. En 1834, al comienzo de la regencia de María Cristina, el Santo Oficio se abolió definitivamente, quedando las labores censorias en manos de Roma y de los obispos.

\subsection{Los responsables de la censura}

Para poder llevar a cabo todas las funciones encomendadas, el Santo Oficio fue creando una estructura organizativa que para mediados del siglo XVI estaba definida. A la cabeza de la institución se sitúa el inquisidor general, que a su vez preside el Consejo de la Suprema Inquisición, máximo órgano de gobierno. Su implantación en el territorio lo ejerce a través de los tribunales de distrito, en el caso del reino de Navarra, tras años de indefinición y cambios de sede, a partir de 1570, el tribunal se asienta en Logroño (Reguera, 1984, pp. 13-22). Estos tribunales están compuestos por dos o tres inquisidores y un número de asistentes con diferentes cometidos. Entre este personal, los hay asalariados y colaboradores sin salario alguno. Estos últimos son los consultores, calificadores, comisarios y familiares. En cuanto a la actividad censoria interesa destacar las figuras de los calificadores y comisarios. Serán los principales artífices en el control de los libros, de interpretar las reglas generales incluidas en los índices o establecer la sospecha en nuevos libros u otros no incorporados.

\subsubsection{Calificadores}

Los calificadores tenían la responsabilidad de dictaminar sobre las declaraciones realizadas por sospechosos de herejía, así como de evaluar los textos recogidos por la Inquisición. Conforme avance el siglo XVII y disminuya la amenaza herética, su labor se dedicará preferentemente a la revisión de los libros que circulan por el país. Para su nombramiento se exigía poseer estudios teológicos, limpieza de sangre, y, a partir de 1627, una edad mínima de 45 años (López, 1986, pp. 346, 359). Los calificadores de mayor prestigio ostentaban cátedras, la mayoría los títulos de maestro o lector de teología. Pese a no estar remunerado, ni gozar del fuero judicial, el reconocimiento público, la proyección personal para otros empleos eclesiásticos o la consideración de la orden religiosa a la que pertenecían, estaban en las motivaciones que impulsaban a solicitar el título de calificador (Guibovich, 2001, pp. 228-229). A principios del siglo XVII se estableció un número limitado en cada tribunal de distrito, esta norma apenas se cumplió, si bien su número fue muy desigual según tribunales. Así, en el tribunal de Logroño en 1632 solo había cuatro y, durante la primera mitad del siglo XVIII, son continuas las quejas por la falta de calificadores (Torres, 2002a, p. 164).

La mayoría pertenecía al clero regular; un rasgo común es que ocupaban cargos de importancia dentro de la jerarquía de sus propias congregaciones. Las principales órdenes religiosas siempre estuvieron representadas, si bien, por su mayor implantación 
territorial, predominaban franciscanos y dominicos y, conforme avanzaba el siglo XVII, la preeminencia de los jesuitas fue más notable (López, 1986, pp. 373-374, 379). En cuanto a otros miembros del clero, destacan los canónigos magistrales.

\subsubsection{Comisarios}

El comisario era el representante y la autoridad visible del Santo Oficio en pueblos y ciudades distantes del tribunal de distrito. Aunque teóricamente no percibía retribución, sí gozaba de privilegios jurídicos. Se procuraba disponer de comisarios por todo el territorio, de manera especial en los principales núcleos de población, puertos marítimos y lugares fronterizos. Para ser nombrados se les exigía ser eclesiásticos «de buena vida y costumbres», limpieza de sangre y rentas propias. A diferencia de los calificadores, no requerían tener una amplia formación teológica ni trayectoria académica, aunque sí suficientes conocimientos para poder desempeñar el cargo. Eran nombrados y actuaban bajo las órdenes directas de los inquisidores del distrito, con los que mantenía una estrecha vinculación, en muchos casos clientelar. En el siglo XVII, tras algunos desmanes, será el inquisidor general quien se reserve la prerrogativa de nombrar a los comisarios de las ciudades más importantes y de las estratégicas comisarías de mar.

Entre sus variadas funciones les competía requisar libros prohibidos, denunciar los dudosos y aplicar los expurgos en librerías y bibliotecas. En las ciudades, la mayoría de los comisarios son canónigos de catedrales o colegiatas, pero el grueso del comisariado estaba formado por clérigos rurales, muchos de ellos titulares de parroquias, residentes en poblaciones de cierto relieve, sin excesivos recursos económicos y un nivel de instrucción irregular. A diferencia de los calificadores, el clero regular tenía menor presencia. Destacan los comisarios de mar, de gran importancia en el tribunal de Logroño, cuya misión principal será la inspección de los navíos extranjeros para impedir la entrada de herejes y de libros heréticos. Funciones similares realizaban los comisarios de aduanas o "puertos secos» que, en el caso de Navarra, se situaban en los límites con Álava, La Rioja y en la línea del Ebro.

En lo que respecta a este tribunal y, en concreto, al territorio de Navarra, a diferencia de otros tribunales, siempre hubo un déficit crónico de servidores inquisitoriales en las zonas fronterizas del Pirineo, incluso en la ciudad de Pamplona, no así en la franja del valle del Ebro, ni en la merindad de Estella, donde nunca faltaron. Esta escasez de personal se acentuó durante la segunda mitad del siglo XVII, aunque mejoró a partir de los años sesenta del siglo XVIII. Así, Pamplona, desde 1682 y durante más de treinta años no contó con presencia inquisitorial. Este vacío era especialmente grave al ser una ciudad fronteriza de constante flujo comercial con Francia (Torres, 2002b, pp. 473-480).

\subsubsection{Censores comisionados}

En principio, solo los calificadores y comisarios podían realizar los expurgos, pero con el considerable aumento de los libros a revisar, se hizo evidente la imposibilidad de inspeccionar las bibliotecas existentes solo con agentes inquisitoriales. Por ello, como se ha señalado, se recurrió a otorgar licencias a conventos, universidades o instituciones 
religiosas para llevar a cabo la revisión de sus bibliotecas. A partir de los años veinte del siglo XVII esta colaboración externa será práctica habitual (Peña, 2015, pp. 5455). Por lo general, se facultaba a los priores, abades, maestros y lectores de teología quienes, una vez efectuadas las revisiones, debían comunicar al tribunal del distrito las actuaciones realizadas en sus bibliotecas. Estos permisos y comisiones se intensificaban en los meses siguientes a la publicación de un nuevo índice, aunque de algún modo será una práctica continua.

En Navarra, prácticamente todas las instituciones religiosas se encargaron de revisar y expurgar sus libros. Máxime si se tiene en cuenta lo señalado sobre la escasez de comisarios inquisitoriales.

\section{EL FONDO ANTIGUO DE LA BIBLIOTECA DE NAVARRA}

Antes de entrar a detallar los libros depositados en la Biblioteca de Navarra en los que se muestra la huella de la Inquisición, conviene exponer el origen de este fondo antiguo -siglo XV al primer tercio del siglo XIX-, que asciende a 14000 ejemplares aproximadamente, de los que alrededor de 3000 son del siglo XVI, más de 4600 del XVII y sobrepasan los 5200 los del XVIII. A estos se añaden unos 1100 editados entre 1801 y 1830. El grueso de la colección procede de la incautación de bibliotecas religiosas afectadas por las desamortizaciones del siglo XIX, una parte más reducida a donaciones particulares y, todavía en menor medida, a adquisiciones.

Durante la Edad Moderna, Navarra contaba con notables bibliotecas eclesiásticas, pero las cruentas primeras décadas del siglo XIX fueron nefastas para la conservación de muchas de ellas. Algunas desaparecieron, otras quedaron muy disminuidas. Las principales bibliotecas intervenidas tras la desamortización fueron las de los conventos suprimidos de Pamplona y, más minoritaria, de otras localidades navarras.

En 1865, la Comisión de Monumentos Históricos y Artísticos de Navarra procedió al traslado de la mayor parte de este fondo desamortizado al Instituto de Segunda Enseñanza de Pamplona. Se depositaron las colecciones de los conventos de Pamplona, así como lo que aún se conservaba de la biblioteca del monasterio cisterciense de Fitero. En 1870 se constituyó en el Instituto la Biblioteca de Navarra con 13000 volúmenes (Elizari, 2000, p. 352), de los que unos 10500 procedían de la desamortización (Panizo, 2000, p. 394). Durante el primer tercio del siglo XX, estos fondos antiguos sufrieron varios traslados, hasta quedar almacenados en el Archivo de Navarra. En 1941, los capuchinos de Pamplona lograron la devolución de los libros de todos sus conventos navarros (Panizo, 2000, p. 450). En 1972, la Biblioteca se trasladó al edificio modernista conocido como «La Agrícola», y es en ese traslado cuando reingresan en bloque los fondos antiguos desamortizados. No obstante, una parte de los mismos, en principio los de temática más histórica, se quedaron definitivamente en el Archivo, formando parte de su biblioteca auxiliar.

Aunque en un porcentaje elevado no se ha podido determinar la procedencia concreta de este fondo desamortizado, se conoce la filiación de un $30 \%$, bien por las marcas de 
propiedad que constan en las portadas, los supralibris en sus lomos, o por exlibris de religiosos de los que se conoce su adscripción conventual. En cifras aproximadas, destacan los libros procedentes de las bibliotecas de los carmelitas descalzos de Pamplona -unos 1100- y de los trinitarios descalzos de la ciudad -unos 700-, así como de los conventos franciscanos de Pamplona y Olite y del monasterio de Fitero -cerca de 500 volúmenes de cada uno-. Con un volumen inferior, figuran los libros de los conventos pamploneses de dominicos, carmelitas calzados y mercedarios -unos 200 de cada uno-, así como otros 150 de los diferentes conventos capuchinos que en su día no retornaron a la orden religiosa. Por último, de forma testimonial se encuentran unos pocos ejemplares provenientes de otros recintos monacales. A todos estos hay que añadir unos 50 ejemplares de los jesuitas de Pamplona y Azpeitia. En todos estos centros religiosos había libros expurgados.

Como es lógico, la gran mayoría de este fondo es de temática religiosa: obras de teología, textos y comentarios bíblicos, Padres de la Iglesia, hagiografías, oratoria sacra, devocionarios, etc. También hay un volumen considerable de libros históricos, jurídicos, de medicina, reales cédulas, etc. Sin embargo, la presencia de obras literarias es escasa. El idioma dominante es el latín, si bien, alrededor de un tercio está en español y conforme se avanza cronológicamente el porcentaje en lenguas vernáculas aumenta.

Junto a este fondo bibliográfico conventual, en la Biblioteca de Navarra también se custodian varios centenares de libros antiguos que proceden de colecciones particulares, de los que algunos de ellos aparecen en los índices inquisitoriales. En 1804, un ilustre navarro, José Goya y Muniáin, bibliotecario en la Biblioteca Real, canónigo de Sevilla y auditor de la Rota, legaba a las instituciones forales un lote de libros. Al menos unos 60 libros de temática religiosa y derecho canónico se localizan en la biblioteca. Más importante es la colección del jurista navarro Manuel de Lejalde († 1830), síndico del reino y miembro del Consejo Real de Navarra (1817-1819, 1828), del que se identifican más de 300 ejemplares de temática jurídica. Por legado testamentario, José Zalba Labarga (1883-1947), archivero, miembro de la Comisión de Monumentos de Navarra y de la Real Academia de la Historia, donó su biblioteca a la Diputación; en ella se localizan alrededor de 60 libros antiguos, algunos expurgados, otros prohibidos.

Finalmente, mencionar varias adquisiciones que, desde los años centrales del siglo XX, ha venido realizando la propia Biblioteca. Algunos libros y folletos del primer tercio del siglo XIX relacionados con el debate inquisitorial, fueron adquiridos por el entonces director de la Biblioteca, Jaime del Burgo, interesado en formar una colección bibliográfica centrada en los conflictos políticos de España durante dicho siglo. En 2003, se efectuó una importante compra de una biblioteca familiar formada, en el siglo XVIII y principios del XIX, por dos médicos rurales navarros, padre e hijo: Miguel Antonio Sanz (1733-1815) y Francisco Javier Sanz (1774-1854)². Es una colección de más de 400 libros, la mayoría obras de medicina con ediciones desde el siglo XVI, entre los que también se encuentran expurgados y prohibidos.

2 Miguel Antonio Sanz ejerció la medicina en diferentes localidades navarras hasta afincarse en San Martín de Unx, mientras que Javier fue el médico del pueblo desde 1810 hasta su jubilación (Leoz, 2005, pp. 13-30). 


\section{LIBROS RELACIONADOS CON LA INQUISICIÓN}

Nos referimos a los libros publicados durante el periodo de vigencia de la institución, que tratan de los procedimientos inquisitoriales, de su potestad, sobre herejes y herejías, de las controversias surgidas en el ocaso de su existencia, de edictos publicados y, por supuesto, de los índices inquisitoriales. En total se han localizado treinta y dos referencias, a las que se suman seis índices, dos suplementos y otros tres índices no elaborados por la Inquisición española. De varios ejemplares se conoce su procedencia y uso por clérigos que colaboraron con el Santo Oficio.

El recorrido se inicia con el Directorium Inquisitorum del dominico del siglo XIV, Nicolau Eymerich. Libro considerado como el manual oficial de procedimiento inquisitorial, tanto de la Inquisición medieval como de la moderna, completada con amplios escolios del también dominico Francisco Peña, experto en jurisprudencia inquisitorial. Hay un capítulo dedicado a la prohibición de libros. En la Biblioteca existen dos ejemplares de sendas ediciones romanas $(1585,1587)$; uno de ellos procede del monasterio de Fitero y perteneció al abad Ignacio de Ibero, que fue calificador de la Suprema y formó parte de la Junta preparatoria del índice de 1612.

Otros tratados inquisitoriales presentes en la Biblioteca son: Lucerna inquisitorum haereticae pravitatis, del inquisidor Bernardo da Como (Roma, 1584), utilizado también como guía legal sobre los métodos inquisitoriales aceptados en los interrogatorios; la obra en tres volúmenes De materiis tribunalium S. Inquisitionis (Roma, 1651-1656), del jesuita español Sebastián Salelles, consultor del Santo Oficio de Malta; dos ejemplares de ediciones lionesas del Tractatus de officio Inquisitionis et modo procedendi in causis fidei $(1649,1669)$ del teólogo y jurista Cesare Carena, fiscal del tribunal de la Inquisición de Cremona y Milán -el ejemplar de 1649 perteneció al abogado pamplonés Manuel de Lejalde-; el Manuale qualificatorum Santiss. Inquisitionis (Palermo, 1642) de Giovanni Alberghini, que analiza todas las desviaciones que debe juzgar el tribunal, desde la herejía a la falsa revelación; la obra Regulare tribunal seu Praxis formandi processus del consultor de la Inquisición romana Pietro Passerini (Roma, 1677), dedicada al proceso inquisitorial; otra obra de derecho inquisitorial, De officio $S$. Inquisitionis circa haeresim (Lyon, 1680) del calificador romano Tommaso del Bene; este ejemplar procede de Fitero y lleva la firma del abad Nicolás de Ardanaz, quien realizó labores censoras en la librería del monasterio. Sobre el trato a los procesados por la Inquisición versa el opúsculo Tractatum de reis coram Sancto Inquisitionis Officio del canónigo, jurista e inquisidor del tribunal de Barcelona, Fernando Calderón de la Barca (Madrid, 1701). Otra obra clásica de la bibliografía inquisitorial es el Tractatus ad defensam Inquisitorum de Sebastiano Guazzini (Ginebra, 1738). En esta sección sobre procedimientos inquisitoriales, es preciso señalar una instrucción publicada en el segundo tercio del siglo XVIII por el tribunal de Logroño, dirigida a los comisarios del distrito, en la que se indica las formas de proceder en las tomas de declaraciones y de comunicarse con los inquisidores ${ }^{3}$.

3 Instrucción que han de guardar los Comissarios del Santo Oficio de la Inquisición en las causas y negocios de Fe, y los demás que se ofrecieren. Aunque no incluye pie de imprenta, está impreso en Logroño, por Matías de San Martín, entre 1730 y 1750. 
Otro grupo de obras es el referido a los herejes y herejías. En primer lugar, cabe destacar el Catalogus haereticorum omnium (Colonia, 1537) del dominico Bernardus de Lutzenburgo, inquisidor en Colonia, Maguncia y Tréveris, acérrimo opositor del luteranismo. De la obra Institutiones catholicae... praecavendas \& extirpandas haereses necessarium, del jurista y consejero de la Suprema, Diego de Simancas, la Biblioteca posee cuatro ejemplares de dos ediciones (Valladolid, 1552, Roma, 1575); uno de los ejemplares procede de Fitero y perteneció al abad Marcos de Villalba, quien expurgó libros siendo abad del convento de San Bernardo en Salamanca. Con tres ejemplares (Amberes, 1565, París 1571,1578) está representada la obra Adversus omnes haereses Libri XIIII del franciscano Alfonso de Castro, reeditada en numerosas ocasiones, que a modo de diccionario expone y refuta todo un catálogo de herejías. Finalmente, la obra del jesuita alemán Jakob Gretser, De iure et more prohibendi expurgandi et abolendi libros haereticos (Ingolstadt, 1603), este autor colaboró con el jesuita Pineda en la elaboración de los índices de 1612 y 1632 (Martínez de Bujanda, 2016, pp. 86-89).

Respecto a la autoridad de la Inquisición subrayar De origine et progressu Oficii Sanctae Inquisitionis (Madrid, 1598), del jurista toledano e inquisidor en Sevilla y Sicilia, Luis de Páramo, en el que defiende la prevalencia de la jurisdicción inquisitorial sobre la civil. Sorprende el libro de Melchor de Macanaz, Defensa critica de la Inquisición contra los principales enemigos... (Madrid, 1788). Ferviente valedor del regalismo y contrario al poder inquisitorial siendo fiscal general del Consejo de Castilla, hacia 1734-1736, caído en desgracia y exiliado, escribió esta obra con el ánimo de granjearse el perdón del Santo Oficio.

Existen varios impresos sobre los ceremoniales y actividades desarrolladas por la Inquisición. Así, la relación de las celebraciones en Zaragoza por el nombramiento de Luis de Aliaga como inquisidor general, compuesta por su paisano Luis Díez de Aux (Zaragoza, 1619); el sermón predicado en Madrid por el jesuita y calificador Agustín de Castro, con motivo de la publicación del índice de 1632, tal como prescribía el protocolo establecido. De 1733 es la relación de un auto de fe celebrado en Lima escrita por Pedro de Peralta Barnuevo (Lima, 1733). Del tribunal de Logroño se localizan dos impresos: el primero es el nombramiento como familiar de la Inquisición de Mateo de Villanueva y su esposa Sicilia de Urrutia, vecinos de Ayega (Valle de Mena, Burgos), está fechado en Logroño en 1661 y firmado por el inquisidor Matías Santos de Samper y el notario del secreto Martín Badarán de Osinalde; incluye el árbol genealógico de ambos pretendientes que demuestra su limpieza de sangre, tal como lo requería el derecho inquisitorial. El segundo, es un edicto contra las supersticiones, oraciones y jaculatorias empleadas para curar ciertas enfermedades del ganado o preservarlo de los lobos; estas prácticas, como indica el propio documento, se condenaban con la excomunión y una multa de doscientos ducados. Desde un enfoque etnográfico es interesante pues describe algunas de estas costumbres populares y detalla frases utilizadas, muchas de ellas expresadas en euskera. El edicto es un pasquín pensado para fijar en la puerta de las iglesias, está fechado en Logroño en 1725 y firmado por los tres inquisidores en activo, los licenciados Sebastián Fuertes, Andrés Francisco de Arratabe y Pablo de Dicastillo. Señala Torres Arce (2002a, pp. 81-82) que la superstición fue el delito más juzgado en la primera mitad del siglo XVIII. 


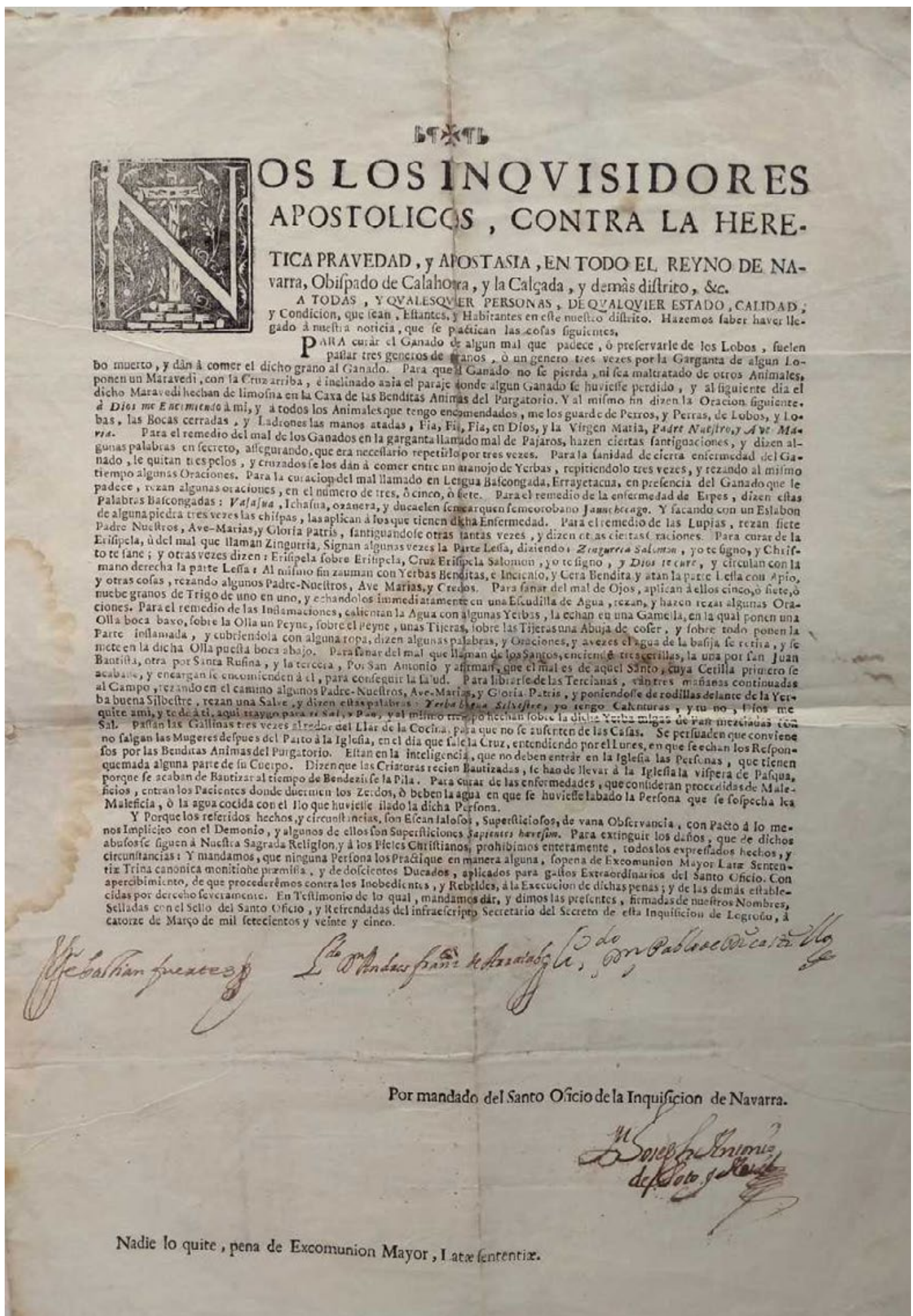

Figura 1. Tribunal de la Inquisición (Logroño). Edicto condenando las jaculatorias empleadas para curar enfermedades del ganado o preservarlo de los lobos. (1725). Sign. VAR-3/002.

\section{0}


En el primer tercio del siglo XIX, período en la que se debate el fin del Antiguo Régimen y, con él, la supervivencia de la Inquisición, se publicaron numerosos textos de controversia entre los opositores de la institución y los partidarios de la misma. Esta literatura inquisitorial está bien representada en los fondos de la Biblioteca. No falta un ejemplar de la Historia crítica de la Inquisición de España de Juan Antonio Llorente (Barcelona, 1835-1836). Jurista y canónigo, funcionario del Santo Oficio hasta que perder sus cargos. Editada en 1822, es considerada la primera historia general publicada sobre la Inquisición española. Del mismo autor se dispone de la Memoria histórica... acerca del Tribunal de la Inquisición, leída en la Real Academia de la Historia... [en] 1811, publicada siendo consejero para Asuntos Eclesiásticos del gobierno bonapartista.

Las Cortes de Cádiz en 1813 acordaron la supresión de la Inquisición. En el transcurso de las discusiones se publicaron numerosos escritos en pro y en contra. Se hallan en la Biblioteca dos impresos anónimos editados en Cádiz, el primero de $1811^{4}$ y el segundo de $1813^{5}$, en los que se utilizan argumentos históricos para justificar su mantenimiento. Con este propósito, el carmelita José de San Bartolomé publicará un alegato titulado El duelo de la Inquisición... (Madrid, 1814). En la otra vertiente hay un folleto titulado Discusión del proyecto de decreto sobre el Tribunal de la Inquisición (Cádiz, 1813) y un breve texto del obispo de Barbastro, Agustín Abad y Lasierra, en favor de su disolución ${ }^{6}$. Tras la restauración de la Inquisición por Fernando VII en 1814, estos dos últimos impresos fueron prohibidos, «aun para los que tienen licencia». Por último, de los años del Trienio liberal y la nueva supresión inquisitorial, hay dos publicaciones satíricas. Un panfleto anónimo titulado Testamento de la Señora de la Vela Verde y yública declaración de sus culpas (Madrid, 1820), que es una feroz crítica a la institución; y un opúsculo de Leandro Fernández de Moratín que rescata el texto impreso en Logroño en 1611 sobre el auto de fe contra las brujas de Zugarramurdi y que adereza con notas irónicas para denunciar la barbarie y la sinrazón de los procesos inquisitoriales ${ }^{8}$.

En lo que respecta a los diferentes índices de libros prohibidos y expurgados, la Biblioteca dispone de ejemplares de la mayoría de ellos, casi todos proceden de los fondos desamortizados. El más antiguo es el índice de Quiroga (1583-1584) y proviene del convento de San Francisco de Pamplona. Se custodia también el de 1612 procedente del monasterio de Fitero y el apéndice al mismo de 1614, cuyo propietario fue el librero pamplonés Martín de Berdún (c. 1580-1638) (Itúrbide, 2015, CD-ROM, pp. 53-54),

4 Carta de un nuevo reflexionador al anti-apologista de la Inquisición... (Cádiz, c. 1811).

5 Establecimiento del Tribunal de la Santa Inquisición en España: sacado del cap. 49 del libro 20 de los Anales de Aragón de Gerónimo de Zurita... (Cádiz, 1813).

6 Copia de la representación del M. R. Obispo de Barbastro... dando las gracias por la abolición del Tribunal de la Inquisición (Cádiz, 1813).

7 La «señora de la vela verde» es el nombre despectivo que se utilizó en la época para nombrar a la Inquisición. $\mathrm{Al}$ parecer se le llamaba así haciendo alusión a la vela de ese color que llevaban en las manos los condenados a muerte o también al verde que se usaba en el escudo del Santo Oficio (Muñoz, 2008, p. 73).

8 Auto de Fe celebrado en la ciudad de Logroño en los días 7 y 8 de noviembre del año de 1610... ilustrada con notas por el bachiller Ginés de Posadilla... (Madrid, 1820). 
pues su firma aparece tras el colofón. En su caso parece que sí cumplió con el mandato para «libreros, corredores y tratantes de libros», de poseer y exhibir un ejemplar del último índice publicado. Del índice de 1640 se localizan dos ejemplares, mientras que son cuatro los de 1707, uno de ellos con la marca de los franciscanos de Pamplona. También existe un ejemplar del suplemento de 1739, así como otro del índice de 1747. Del último publicado en 1790, existen dos ejemplares, uno de ellos procede de la biblioteca de la familia Sanz de San Martín de Unx y lleva la firma de D. Joaquín Ligero, párroco del lugar.

Otras tres referencias completan este listado de índices inquisitoriales. El primero es el llamado «Índice de Amberes» (Index expurgatorius librorum..., 1571), novedoso por expurgar algunas obras sin necesidad de prohibirlas. Su principal compilador fue Arias Montano por encargo de Felipe II, y se tuvo en cuenta en la elaboración del expurgatorio español de 1584. El segundo es un índice de libros prohibidos publicado por la Inquisición portuguesa (Lisboa, 1597) que recoge, con añadidos, el índice romano de 1596. Finalmente, hay dos ejemplares del tomo primero y único publicado del Indicis librorum expurgandorum..., en su segunda edición (Bérgamo, 1608), elaborado por Guanzelli da Brisighella, maestro del Sacro Palacio y miembro de las congregaciones romanas de la Inquisición y del Índice. Fue un intento frustrado de confeccionar un índice expurgatorio que, en 1613, la Congregación lo retiró, para continuar publicando únicamente listados de libros prohibidos.

\section{LIBROS EXPURGADOS}

En el conjunto del fondo antiguo, se han localizado 476 ejemplares expurgados. Para su detección se ha confrontado la consulta del catálogo automatizado de la Biblioteca de Navarra ${ }^{9}$, que describe la totalidad del fondo antiguo, e incluye los datos específicos de cada ejemplar, con el índice acumulativo de libros prohibidos y expurgados que recoge Martínez de Bujanda ya mencionado (2016, pp. 263-1216). Como resultado de este cotejo, se han añadido más ejemplares con signos de expurgo cuya condición no recoge el catálogo de la biblioteca.

Que supongan un 3,7\% del total del fondo antiguo puede parecer una cifra baja. Sin embargo, no lo es al considerar que la mayor parte del fondo procede de bibliotecas conventuales, en las cuales, por su propia naturaleza, dominaban los libros totalmente acordes con la ortodoxia. Es un porcentaje similar a los libros expurgados en la Biblioteca Histórica de Santa Cruz de Valladolid (Galindo, 2015, pp. 105-106) e inferior a los registrados en la del Colegio jesuita de Montilla (Sánchez, 2016, p. 55) ${ }^{10}$. De cualquier manera, conforma un conjunto suficientemente representativo para ilustrar aspectos y pautas de la actividad censoria inquisitorial: clases de autores según los índices, obras

9 http://www.navarra.es/opac/abnetcl.exe/

10 En la Biblioteca Histórica de Santa Cruz de Valladolid, sobre un conjunto aproximado de 14000 libros, la autora recoge un total de 508 ejemplares expurgados, un 3,62\%. En el Colegio jesuita de Montilla, sobre un total de 2062 libros, el autor recoge 124 ejemplares expurgados, un $6 \%$. 
más expurgadas, datos cronológicos y geográficos de las ediciones, índices más utilizados, métodos de expurgo, procedencia de los ejemplares, características comunes de los censores, etc. Evidentemente, por un tema de espacio, se renuncia a presentar el listado con todas las obras y ejemplares expurgados, limitándonos a mencionar algunos autores y títulos.

\subsection{Autores, obras y ejemplares}

Los 476 ejemplares se corresponden a 331 obras relacionadas con 311 autores, anotadores, comentaristas, traductores, etc., repartidos en 427 ediciones

Tabla 1. Autores, obras y ejemplares

\begin{tabular}{cccc} 
Autores & Títulos & Ediciones & Ejemplares \\
\hline 311 & 331 & 427 & 476 \\
\hline
\end{tabular}

Hay distintas ediciones de una misma obra con más de un ejemplar, así como autores con varias obras expurgadas. Por ejemplo, de la Opera omnia de san Agustín, con comentarios y notas de Erasmo de Roterdam y Vives, se localizan seis ediciones -París, 1541, 1555, 1571; Venecia 1551, 1570; Lyon, 1560-63-, algunos volúmenes profusamente expurgados, a los que se añade el expurgo a conciencia en dos ejemplares de la De civitate Dei Libri XXII (Basilea, 1542, París, 1580). En la misma línea, la Opera omnia de san Jerónimo, también comentada por Erasmo, y expurgada en las cinco ediciones existentes: Basilea, 1524-26, 1553, 1565; Lyon, 1530; París, 1533-34. Por señalar ejemplos de un mismo autor y obra, en distintas ediciones y con más de un ejemplar en cada una de ellas: Diego de Estella y su Evangelium secundum Lucam enarrationum, con 7 ejemplares expurgados: Salamanca, 1575 (2), Alcalá, 1577-1578 (2) y Salamanca, 1582 (3). Otro caso similar, las Consideraciones sobre todos los Evangelios de los Domingos y Ferias de la Quaresma de Hernando de Santiago, con 7 ejemplares expurgados de diversas ediciones: Salamanca, 1597, Barcelona, 1598, Lisboa, 1598, Madrid, 1599, Valladolid, 1606. Abundan los autores con ejemplares expurgados de diferentes obras. Justus Lipsius (3 obras, 4 ejemplares), Antoine Mizauld (4 obras), Johann Wild ( 3 obras, 5 ejemplares), Manoel Rodrigues ( 3 obras, 10 ejemplares), Tycho Brahe ( 3 obras), etc. De todos ellos, es el humanista Erasmo de Roterdam, el de mayor presencia en la Biblioteca y el más expurgado, tanto en las obras propias -en 10 de los 14 títulos que posee-, como en los libros de autores clásicos y patrísticos con anotaciones y comentarios suyos. Como autor destacan los expurgos en sus obras Antibarbarorum (Basilea, 1520), In primum et secundum psalmum... paraphrasis (Basilea, 1525), Parabolae sive Similia (Estrasburgo, 1525), Querela pacis... (Lyon, 1529), Apophthegmatum opus (París, 1533). Como editor literario y comentarista, además de los señalados, está expurgado con encono un ejemplar del texto de Hilario de Poitiers, Lucubrationes quotquot extant (Basilea, 1550), así como sus comentarios en obras de Ovidio (Frankfurt, 1601), Séneca (Lyon, 1555) o Arnobio el joven (Basilea, 1560). 


\subsubsection{Clases de autores según los índices}

Ya se ha comentado que a partir del índice de 1612 se dividen los autores y las obras en tres clases.

Tabla 2. Clases de autores

\begin{tabular}{lrr} 
Clases & Autores & \multicolumn{1}{c}{$\%$} \\
\hline $1^{\mathrm{a}}$ clase & 72 & 23,16 \\
\multicolumn{1}{c}{ Padres de la Iglesia } & 14 & 4,50 \\
\multicolumn{1}{c}{ Autores clásicos } & 20 & 6,43 \\
\hline $2^{\mathrm{a}}$ clase & 190 & 61,09 \\
\hline $3^{\mathrm{a}}$ clase & 2 & 0,64 \\
\hline No Índices & 13 & 4,18 \\
\hline & & 100,00 \\
\hline
\end{tabular}

Como en este apartado se examinan libros expurgados y no prohibidos, es lógico que, de los 311 autores, 190 (61\%) se incluyan en la segunda clase, esto es, autores católicos con alguna obra afectada por la censura. Más de la mitad, el $53 \%$, son españoles y/o portugueses. En numerosos casos con mínimas correcciones de palabras o frases, aunque en ocasiones se censuran amplios párrafos o páginas enteras. Por mencionar algunos nombres de distintas cronologías y temas: Alfonso de Madrigal, beato Ángel de Clavasio, Arias Montano, Cristóbal de Avendaño, Martín de Azpilcueta, Francisco Blasco de Lanuza, Bonacina, Cabassut, Castillo de Bobadilla, Chasseneux, Diego de Estella, Dionysius Cartusianus, Cristóbal de Fonseca, Francisco de Osuna, Bartolomeo Fumo, Genebrard, Antonio Gómez, Antonio de Guevara, Henrique Henriques, Huarte de San Juan, Jerónimo de Azambuja, Lefévre d'Étaples, Martínez de Cantalapiedra, Gaspar de Mello, Silvestro da Prierio, Benito Noydens, Balthazar Paes, Manoel Rodrigues, Sabellico, Alfonso Salmerón, Sannazaro, Savonarola, Francisco de Tornamira, Valles de Covarrubias, Martín de Torrecilla, Alonso de la Vega, Francisco de Vitoria, Martín de Vivaldo, Johann Wild (Fero), Diego de Zúñiga.

Sin embargo, es notable el número de autores adscritos a la primera clase, esto es, condenados por herejes o sospechosos de herejía, de los que se permiten, expurgados y con la nota de "Auctor damnatus", sus obras no religiosas, así como las compilaciones de textos patrísticos y de autores clásicos. La nómina alcanza 72 nombres, supone algo más de un $23 \%$ del total. Se pueden agrupar en: autores con obras propias, los partícipes -anotadores, comentaristas, prologuistas, traductores, editores literarios, impresores- en ediciones de textos de los Padres de la Iglesia y clásicos grecolatinos, en los que, sobre todo, se censuran dedicatorias, epístolas y prólogos introductorios, y, por último, los personajes que participan de ambos grupos. Por destacar algunos nombres del primer grupo: Borcholten, Brahe, Theodor de Bry, Philipp Camerario, Du Moulin, Gesner, Gruterus, Hotman, Libavius, Origanus, Stucki, Wecker, Wesenbeck. Entre los anotadores y comentaristas: Joachim Camerarius, Janus Cornarius, Henri y Robert 
Estienne, Lycosthenes, Melanchthon, Musculus, Oecolampadius, Oporinus, Salmuth, Toxites, Hieronymus Wolf, Xylander. Por último, autores con obras propias y otras en las que colaboran: Isaac Casaubon, Erasmo, Hadrianus Junius, Justus Scaliger, etc.

Entre las obras expurgadas de antiguos Padres de la Iglesia, editadas y "corrompidas» por heréticos, además de las ya citadas, destacan los textos de san Atanasio compilados por Pieter Nanninck (Basilea, 1556); de san Basilio (París, 1547) o san Epifanio (París, 1566), ambos traducidos y comentados por Janus Cornarius; de Eusebio de Cesarea en ediciones prologadas por el luterano Marcus Hopper (Basilea, 1549, 1559) o la anotada por Scaliger (Leyden, 1606); de san Gregorio Niseno (Colonia, 1551), cuyo editor literario es Johannes Oecolampadius. Otros autores patrísticos con versiones expurgadas: san Juan Crisóstomo, Tertuliano, san Irineo, etc. De autores clásicos cabe destacar las versiones de textos de Cicerón, realizadas por Camerarius (Basilea, 1540) o Melanchthon (Lyon, 1545); de Diógenes Laercio con anotaciones de Casaubon e impresa por Henri Estienne II (Ginebra, 1594); de Jenofonte comentada por Leunclavius y Aemilius Portus (Frankfurt, 1594), de Plinio Cecilio anotada por Lycosthenes e impresa por Oporinus (Basilea, 1547), una edición incunable de Suetonio con comentarios de Filippo Beroaldo (Bolonia, 1493). Otros autores grecolatinos con versiones expurgadas: Heródoto, Plutarco, Terencio, Ovidio, Tucídides, Polibio, etc.

La mayoría de estos autores incluidos en la primera clase, aunque no todos, proceden de ámbitos geográficos y entornos culturales luteranos o calvinistas, ninguno es de origen español. Los hay humanistas, científicos, juristas, también algún teólogo, todos desarrollan su labor durante el siglo XVI y primeras décadas del siglo XVII. Esta circunstancia es lógica por cuanto la presión de la censura inquisitorial en su lucha contra la herejía protestante, fue más intensa durante estas fechas, en pleno apogeo del Santo Oficio.

La presencia de obras integradas en la tercera clase -anónimas o consideradas como tales- es testimonial, solo se localizan dos casos, el más significativo es la obra Epigrammatum graecorum... (Frankfurt, 1600), en la que colaboran Vincentius Opsopoeus y Henri Estienne II.

Finalmente, se localizan trece autores con alguna de sus obras expurgadas, que no aparecen en los índices inquisitoriales. Salvo dos casos en los que en un determinado momento la obra estuvo presente en la censura inquisitorial ${ }^{11}$, el resto se debe a la actitud rigorista del comisario o calificador o la denuncia de algún lector, consecuencia de cierta arbitrariedad en la aplicación de los criterios censores habituales (Pardo, 2003, pp. 1012). A mediados del siglo XVII, el comisario Sebastián Gallardo expurga cinco de esos títulos. Algunos de estos expurgos no justificados serán posteriormente criticados por otros censores. A finales del siglo XVI, el comisario Pedro Fernández de Arguedas, tras la denuncia recibida de Fr. Bernardino de Agüero, guardián del convento franciscano

11 Así, el sermonario de Manuel Garay, Paréntesis del ocio (Pamplona, 1740), que fue expurgado conforme a un edicto de 1745, pero que no se incluyó en el índice de 1747; la obra teológica de Pierre de La Palud, Lucubrationum opus in quartum sententiarum (Salamanca, 1552), cuyo expurgo solo aparece en el índice de 1632, desapareciendo en los siguientes índices. 
de Ágreda, censura una frase en la Summa praedicantium... de Filippe Dias (Salamanca, 1589). Sin embargo, hay otra anotación, fechada en 1601, del comisario y canónigo de Burgos, Martín Aristi, sobre la improcedencia de dicha censura. Otro ejemplo más radical lo proporciona la nota critica al expurgo realizado en el ejemplar del Compendium spiritualis doctrinae ex variis sanctorum patrum... de Bartolomé de los Mártires (Roma, 1603), que indica: «El autor que borró este libro y lo çensuró pudiera dexar de haçerlo, pues no fue compelido a ello por la Inquisición sino por su antojo y fue temerario» ${ }^{12}$.

Hay que mencionar los ejemplares de Biblias, una de las mayores preocupaciones de la censura inquisitorial. Se localizan quince ejemplares expurgados correspondientes a ocho ediciones ${ }^{13}$ que presentan en sus portadas anotaciones de haber sido examinadas, si bien las correcciones apenas son perceptibles. A destacar la edición salmantina de la Biblia sacra de Vatablo (1584), preparada por Robert Estienne, cuya impresión fue controvertida. Tras varias enmiendas, se publicó con el permiso del inquisidor general Quiroga, si bien sufrió más correcciones en los sucesivos índices expurgatorios como se atestigua en los dos ejemplares de la Biblioteca.

\subsubsection{Ejemplares expurgados más de una vez}

Otro aspecto a reseñar es la reiteración de revisiones realizadas. Hay obras que por su «peligrosidad» fueron examinadas y/o expurgadas varias veces a lo largo del tiempo, como consta en sus portadas o primeras páginas en las que se anota el índice expurgatorio utilizado. Así, 81 ejemplares (17\%) fueron inspeccionados conforme a varios índices; en 65 ejemplares se anotan dos revisiones, tres en 15 ejemplares, incluso hay uno, el tomo V de la Opera omnia de san Agustín (París, 1555) que incluye De civitate Dei, que se revisó en cuatro ocasiones conforme a los índices de 1584, 1612, 1632 y 1640. Entre las obras más comprobadas se encuentran el libro de filosofía natural del médico Vallés de Covarrubias, De sacra philosophia (Lyon, 1592), las obras del humanista Justus Lipsius, Politicorum sive Civilis doctrinae libri sex (Amberes, 1599) y del jurista François Douaren, De sacris Ecclesiae ministeriis ac beneficiis libri VIII (París, 1564), o del también médico Johann Wecker, Medicinae vtriusque syntaxes (Basilea, 1601). Además, ejemplares de obras de Du Moulin, Erasmo, Herolt, Vivaldo, y, por supuesto, de textos patrísticos. Aunque son más frecuentes las revisiones conforme a índices correlativos (1584-1612, 1640-1707), se dan casos en los que las anotaciones aluden a índices más espaciados (1584-1640, 1612-1707).

\subsubsection{Cronologías y lugares de impresión}

Se ha indicado cómo la censura inquisitorial fue más intensa en la etapa de mayor amenaza de las ideas heréticas, esto es, hasta mediados del siglo XVII. Obviamente, los índices recogen los autores y libros hasta la fecha de publicación de cada uno de ellos. Los datos cronológicos del fondo expurgado son coherentes con esta referencia general.

12 Sign. 109-13-1/117.

13 Biblia sacra ex Sanctis Pagnini (Lyon, 1542), Biblia sacra cum glossis interlineari \& ordinaria Nicolai Lyrani (Lyon, 1545; París, 1589), Biblia Sacra Vulgatae (Venecia, 1603), etc. 
Tabla 3. Cronología

\begin{tabular}{|c|c|c|c|c|}
\hline Siglos & Núm. obras (ediciones) & $\%$ & Núm. obras (ejemplares) & $\%$ \\
\hline $\mathrm{XV}$ & 1 & 0,23 & 1 & 0,21 \\
\hline $\mathrm{XVI}$ & 274 & 64,17 & 305 & 64,07 \\
\hline XVII & 127 & 29,75 & 143 & 30,05 \\
\hline XVIII & 25 & 5,85 & 27 & 5,67 \\
\hline XIX & 0 & 0,00 & 0 & 0,00 \\
\hline Total & 427 & 100,00 & 476 & 100,00 \\
\hline
\end{tabular}

Así, en el conjunto de ediciones y ejemplares dominan de forma aplastante, cerca del $94 \%$, las obras publicadas en los siglos XVI y XVII. Al diferenciar por siglos, un $64 \%$ del total son del siglo XVI, seguidos a distancia, un $30 \%$, los publicados en el siglo XVII. Cabe precisar que el $70 \%$ se publicó durante la segunda mitad del siglo XVI y primera del XVII ( $48 \%$ y $22 \%$ respectivamente). Los de la primera mitad del siglo XVI suponen el $16 \%$, y de la segunda mitad del siglo XVII descienden al $7 \%$. La disminución continúa de forma notoria en las obras del siglo XVIII, poco más del $5 \%$ del total, siendo algo superior las editadas en su primera mitad. La ausencia de expurgos es total en los libros del primer tercio del siglo XIX.

No hay contradicción entre el mayor número de libros expurgados de los siglos XVI y primera mitad del siglo XVII, en relación con el conjunto del fondo antiguo de la Biblioteca, en el que el volumen de libros de aquellas fechas es menor a los de la segunda mitad del siglo XVII y siglo XVIII. Varios factores conexos explican esta discordancia. Por un lado, es el resultado de su procedencia conventual, en el que dominan las obras de teología, exégesis, derecho canónico, sermonarios, etc., y no abundan las obras científicas, ni de la literatura profana. En relación con estos contenidos, los índices inquisitoriales son acumulativos y el grueso de libros a expurgar -autores heréticos y humanistas, textos y comentarios bíblicos, patrísticos, teológicos, autores clásicos, etc.-, están ya presentes en el índice de 1640, por lo que un porcentaje elevado de los libros expurgados es anterior a dicha fecha. Además, las nuevas incorporaciones en los índices del siglo XVIII tuvieron más que ver con la religiosidad y devoción popular (Collantes, 2001, pp. 101-103), las costumbres y moral pública, las doctrinas jansenistas o los escritos de tinte político y filosófico, temas todos ellos con poca presencia en los idearios ortodoxos de las órdenes religiosas y, por consiguiente, en sus bibliotecas. Sin olvidar tampoco que, desde mediados del siglo XVII, la actividad inquisitorial disminuye en todos sus frentes, lo que también afecta al control de las publicaciones, las delaciones y revisiones de libros.

En su afán por ejercer un férreo control ideológico, una de las principales actividades desarrolladas por la Inquisición fue la supervisión de los libros importados, bien por los comisarios de puertos y aduanas o mediante inspecciones a las librerías. Pese a las trabas interpuestas, existía una amplia demanda de libros editados en el extranjero y la 
circulación de libros europeos siempre fue importante. Esta demanda estaba favorecida por el desarrollo editorial en muchas ciudades europeas, muy superior a la imprenta española, a su capacidad para asumir costosos proyectos editoriales y ofrecer mayor variedad temática.

Tabla 4. Países de publicación

\begin{tabular}{|c|c|c|c|c|}
\hline Países & Núm. obras (ediciones) & $\%$ & Núm. obras (ejemplares) & $\%$ \\
\hline Francia & 145 & 33,96 & 158 & 33,20 \\
\hline España & 122 & 28,58 & 142 & 29,84 \\
\hline Alemania & 44 & 10,31 & 44 & 9,24 \\
\hline Suiza & 42 & 9,84 & 51 & 10,71 \\
\hline Italia & 36 & 8,43 & 38 & 7,98 \\
\hline Bélgica & 22 & 5,15 & 26 & 5,46 \\
\hline Portugal & 7 & 1,63 & 8 & 1,68 \\
\hline Holanda & 6 & 1,40 & 6 & 1,26 \\
\hline Otros & 3 & 0,70 & 3 & 0,63 \\
\hline Total & 427 & 100,00 & 476 & 100,00 \\
\hline
\end{tabular}

Por lo que no sorprende que solo el $28 \%$ de los libros expurgados sean españoles, mientras que las ediciones francesas suponen casi el $34 \%$, y los libros editados en Alemania y Suiza un $10 \%$ respectivamente. La Inquisición tenía claro que la herejía venía de fuera y especialmente de aquellos países como Alemania, Suiza u Holanda, en los cuales había tenido mayor implantación la Reforma. Al relacionar los países de edición con las fechas de publicación, se comprueba que la gran mayoría de libros extranjeros expurgados se editaron en el siglo XVI. El $74 \%$ de los editados en Francia, el $89 \%$ de las ediciones suizas, el $78 \%$ de los editados en Bélgica. Más equilibrados están los porcentajes de las ediciones alemanas, un $48 \%$ son del siglo XVI y un $52 \%$ del siglo XVII. Llama la atención los pocos libros extranjeros del siglo XVIII, en especial franceses, teniendo en cuenta que los índices de 1747 y 1790, recogen numerosos impresos franceses. Salvo los editados en Italia, que suponen un $14 \%$ de todos los libros italianos expurgados, el resto no llega ni al $1 \%$. A nuestro entender, este dato en parte se explica por el relativo desinterés entre el común del clero conventual por las ideas que llegaban de Europa (jansenistas, enciclopedistas, etc.), que se traduce en la casi inexistencia de estos temas en sus bibliotecas.

En lo que respecta a las ediciones españolas, la cronología de los libros expurgados está mucho más repartida entre el siglo XVI (48\%) y el XVII (40\%), y es minoritaria las del siglo XVIII (12\%). Las razones de la notable disminución de obras dieciochescas ya han sido expuestas, los índices inquisitoriales de este siglo se centrarán más en temas relacionados con la religiosidad popular, obras profanas y temas filosóficos y políticos, de poca demanda en los ambientes conventuales. 
En este conjunto de obras y ediciones expurgadas surgen 55 lugares de impresión, si bien 38 localidades (69\%) solo aparecen una vez. Destaca la considerable importancia de ciudades como Lyon (19\%) y París (13\%), dos de los principales centros editores europeos de mayoría católica, un tercio de todos los libros expurgados están editados en ambas ciudades. Otras dos ciudades católicas que se distinguen son Venecia (22 ediciones) y Amberes (16 ediciones). De las ediciones venecianas prevalecen las del siglo XVI, centradas en temas relacionados con la teología y el derecho canónico. De Amberes conviene reseñar el ejemplar censurado con encono de los Comentarios... sobre el catechismo christiano (1558) de Bartolomé de Carranza, si bien en los índices se incluye entre las obras prohibidas.

En cifras relevantes se sitúan otras ciudades europeas como Basilea, Frankfurt, Colonia, y en menor medida, Roma, Ginebra, Lovaina y Estrasburgo. Mención especial requieren las obras editadas en Basilea (32 títulos, 7,5\%) y Frankfurt (21 títulos, 5\%), dos ciudades editoras del mundo protestante, en donde se concentra buena parte de los libros de los autores englobados en la primera clase. De Basilea proceden la mayoría de las obras expurgadas de Erasmo de Roterdam, así como muchas de las ediciones comentadas de los Padres de la Iglesia y de textos grecolatinos. También figuran obras de temática no religiosa: De re metallica libri XII (1556) de Georg Agrícola; Lexicon sive Dictionarum graecolatinum (1557) de Hadrianus Junius, Chronología hoc est Supputatio temporum ab initio mundi (1577) de Mercator \& Beroaldo; Romanarum antiquitatum libri decem (1583) de Johann Roszfeld; Sudiae Historica... (1581) de Hieronymus Wolf. A Frankfurt corresponden, además de ediciones comentadas de autores clásicos (Ovidio, Plutarco, Jenofonte, Tucídides...), obras como Americae Historia (1590-1605) e Indiae Orientalis Historia (1598-1607) editados por Theodor Bry; Meditationes historicae (1609) de Philipp Camerario; Lampas sive fax artium liberalium (1602-1607) de Gruterus; Discursus politici in Aristotelis de Republica libros (1610) de Scherb; y libros científicos como Historiae animalium de Gesner (1617-1621); dos libros de Alchymia (1606, 1607) de Libavius; Commentarii... in Hippocratis (1602) de Mercuriale; Dierum Canicularium (1642) de Maioli; Thesaurus Chirurgiae (1610) de Uffenbach.

En cuanto a los libros españoles aparecen 16 ciudades, nueve de ellas con una sola edición. Como es previsible, sobresalen los publicados en Madrid (42 títulos, 9,8 \%), primer centro editor desde el siglo XVII. Sin embargo, aun siendo una cifra considerable, suponen la mitad de los procedentes de Lyon e inferior a los editados en París. Entre los libros madrileños, los del siglo XVII suponen el $72 \%$, mientras que un $18 \%$ son del siglo XVIII y un $10 \%$ del siglo XVI. Le sigue Salamanca (26 títulos, $6 \%$ ), prácticamente todos se editaron en el siglo XVI. Mientras que en Madrid no se introduce la imprenta hasta 1566 , Salamanca, con una potente universidad, fue una de las principales ciudades impresoras durante dicho siglo. Otras ciudades con cierta presencia son: Barcelona, Valladolid y Alcalá de Henares. Editados en Pamplona aparecen seis títulos. A destacar: Primera parte de las Postrimerías del hombre (1608) de Pedro de Oña, Palestra critico-medica... de Antonio Rodríguez (1734), o Chronographía y repertorio de los tiempos... (Pamplona, 1585) de Francisco de Tornamira. 


\subsubsection{Materias y temas}

Tabla 5. Materias

\begin{tabular}{|c|c|c|c|c|}
\hline Materias & Títulos & $\%$ & Ejemplares & $\%$ \\
\hline Religión & 185 & 55,9 & 301 & 63,23 \\
\hline Derecho & 34 & 10,28 & 49 & 10,3 \\
\hline Historia & 32 & 9,67 & 36 & 7,57 \\
\hline Ciencias & 32 & 9,67 & 34 & 7,14 \\
\hline Filología/Literatura & 27 & 8,15 & 32 & 6,72 \\
\hline Filosofía & 10 & 3,02 & 10 & 2,10 \\
\hline Política & 4 & 1,20 & 6 & 1,26 \\
\hline Otros & 7 & 2,11 & 8 & 1,68 \\
\hline Total & 331 & 100,00 & 476 & 100,00 \\
\hline
\end{tabular}

Como no podía ser de otra manera, dominan de forma notable los libros de temática religiosa. Los 185 títulos que se corresponden con 301 ejemplares suponen casi el $56 \%$ del total de títulos y algo más del $63 \%$ de ejemplares. Es la categoría temática donde más ejemplares hay de un mismo título, incluso, de una misma edición. El dato es coherente con la procedencia de la mayor parte del fondo antiguo. También con el objetivo prioritario de la censura inquisitorial en defensa de la fe católica. Libros religiosos, que, por otro lado, serán los más publicados hasta bien entrado el siglo XVIII.

Desglosando por temas destacan las obras relacionadas con la teología dogmática y moral -55 títulos-, los comentarios bíblicos (exégesis bíblica) -37-, la oratoria sacra (sermones, homilías) -24-, los Padres de la Iglesia -19-. A estos temas se añaden otros 42 títulos diseminados en libros alusivos a la historia eclesiástica, incluyendo las órdenes religiosas, obras de espiritualidad, devocionales, hagiografías, etc. Con la salvedad de los textos patrísticos, casi todos publicados en Suiza (Basilea) y Francia, la gran mayoría se editaron en los países católicos, por este orden: España, Francia, Italia y Bélgica.

A gran distancia se sitúa el resto de materias. Los libros jurídicos (derecho canónico, civil y romano) suponen algo más del $10 \%$ de títulos, en su mayoría publicados en Francia, Italia y España. Los temas científicos e históricos apenas sobrepasan el $9 \%$ en cada caso. Por detrás se sitúan los libros relacionados con la filología y la literatura clásica, y a mucha distancia los de contenidos filosóficos y políticos, junto con una miscelánea de temas variados (máximas y aforismos, etc.).

Respecto a los escasos libros científicos, los datos corroboran lo indicado por Pardo Tomás al señalar el peso de las ediciones procedentes de Basilea y Frankfurt (1991, pp. 131, 193, 231). En este caso, de los 32 títulos científicos, un $43 \%$ están publicados en Alemania o Suiza. De Francia procede el $28 \%$, en su mayoría impresos en París y, 
solo 4 títulos se editaron en España. Dentro de las obras científicas, la medicina con 11 títulos ocupa un lugar destacado, suponen el $34 \%$, seguida de los temas de astronomía y astrología (28\%), entre ambas áreas suman el $62 \%$. De las 32 obras de temática histórica, al igual que en las científicas, un porcentaje elevado (37\%) están editadas en Alemania, seguido por Suiza ( $28 \%$ ), 5 en Francia, 2 en Holanda y solo 3 en España.

\section{2. Índices más mencionados y cronología de los expurgos}

Hay dos datos llamativos: el alcance de los índices de 1640 y 1707 que son, con diferencia, los más mencionados y el notable descenso de libros expurgados a partir de la segunda mitad del siglo XVIII.

Tabla 6. Mención de los Índices

\begin{tabular}{lrrr} 
Índices & Menciones & $\%$ & Ejemplares \\
1584 & 35 & 6,28 & \\
\hline 1612 & 53 & 9,52 & \\
\hline 1614 (Apéndice) & 2 & 0,36 & \\
\hline 1632 & 33 & 5,92 & \\
\hline 1640 & 213 & 38,25 & \\
\hline 1707 & 118 & 21,18 \\
\hline 1739 (Suplemento) & 2 & 0,36 \\
\hline 1747 & 7 & 1,30 \\
\hline 1790 & 17 & 3,05 & \\
\hline 1805 (Suplemento) & 6 & 1,07 & \\
\hline Otros (edictos, decretos) & 16 & 2,91 & \\
\hline Sin fecha & 54 & 9,80 & \\
\hline & 557 & 100,00 & \\
\hline
\end{tabular}

El primer dato exige matizarlo pues, de algún modo, las cifras están distorsionadas. Así, de los 213 ejemplares expurgados conforme al índice de 1640, 56 de ellos (26\%) están expurgados por dos monjes del monasterio de Fitero, de su biblioteca; es más, uno de ellos, Fr. Jacinto de Arellano, firma 45 expurgos. Algo similar sucede con los 118 ejemplares expurgados según el índice de 1707. Dos censores depuran 49 ejemplares (41,5 \%); uno de ellos, Fr. Joaquín Salvador, también de Fitero, firma la revisión en 34 ejemplares, y el trinitario Fr. Juan de la Anunciación, 15 libros de su convento. Si se descuentan estos ejemplares de ambos índices, los porcentajes son más equilibrados, así las menciones al índice de 1640 supondrían el $28 \%$ y al índice de 1707 el $12 \%$. Pese a esta corrección porcentual, ambos índices fueron los más utilizados para las censuras. En parte coinciden con los datos que aporta la Biblioteca Histórica de Santa Cruz de 
Valladolid, en la que ambos índices son los más mencionados, aunque en distinto orden, será el índice de 1707 el más empleado (Galindo, 2015, pp. 82, 97).

Los datos de la Biblioteca de Navarra confirman las conclusiones de la historiografía. La actividad censoria crece en intensidad hasta las décadas centrales del siglo XVII. Que la mención al índice de 1632 sea menor que las referidas a los índices anteriores tiene que ver con el breve intervalo que estuvo vigente. Por otro lado, aunque las menciones al índice de 1707 sean elevadas, conforme avanza el siglo XVIII se comprueba un brusco descenso de obras expurgadas y, por ende, de menciones a los índices de 1747 y 1790, pese al ligero repunte de este último. En este caso, esta disminución se debe al descenso de las nuevas obras a expurgar en proporción al número de nuevas obras prohibidas (Defourneaux, 1973, p. 34), así como a la poca coincidencia entre los nuevos intereses temáticos de la censura inquisitorial y los fondos bibliográficos existentes en las bibliotecas eclesiásticas.

La Inquisición también se valía de la promulgación de edictos con prohibiciones o expurgos de libros delatados durante los intervalos cronológicos entre índices. Generalmente, esos edictos se incorporaban en la edición del siguiente índice. En lo que respecta a la Biblioteca, son pocos -16 ejemplares- los que mencionan algún edicto en su expurgo. Tres de ellos fueron promulgados en el siglo XVII, el resto son del XVIII. Por ejemplo, la obra Asserta theo-subtilia vel theologica sisthemata de essentia de Gil Becerra (Barcelona, 1737), expurgada conforme a un edicto de 1745; la Notitia Ecclesiastica historiarum... de Cabassut (Venecia, 1772), expurgada en aplicación de un edicto de 1793. En ocasiones, los edictos se refieren a obras publicadas en décadas muy anteriores no examinadas en su momento. Así, las Quaestiones morales theologicae de Leandro del Santísimo Sacramento (Lyon, 1664), se expurga conforme a un edicto de 1731, o la parte segunda de los Sermones de Antonio Vieira (Madrid, 1678), fue depurado según un edicto de 1776.

Pese al notable aumento de títulos en los sucesivos índices inquisitoriales, el crecimiento exponencial de la producción bibliográfica en toda Europa ocasionó pronto un considerable retraso entre la fecha de publicación de una obra, su examen por los calificadores y su inclusión en los índices. Este hecho, evidentemente, mermó la eficacia de la acción represora del Santo Oficio (Pardo, 1991, pp. 140-142, 344). Esta relativa incapacidad se veía agravada por el desfase cronológico entre las obras incluidas en los índices y la acción real de dicho expurgo en cada biblioteca y/o librería. Aunque, tras la publicación de un nuevo índice, se establecía un límite de tiempo para la revisión de libros y la actividad de los censores se intensificaba en los meses siguientes, sin embargo, se constata una importante moratoria entre la aparición de una obra en el índice expurgatorio y su revisión efectiva. Al analizar los ejemplares censurados conforme a los índices más mencionados -1640 y 1707-, se comprueba que un número significativo de títulos ya estaban recogidos en índices anteriores. De los 213 ejemplares expurgados que aluden al índice de 1640, en 165 de ellos $(77 \%$ ) es la única o primera mención de revisión que se anota. De los cuales, 19 títulos ya aparecían en el índice de 1584 y otros 80 en el de 1612. Algo similar, aunque en menor medida, ocurre con el índice de 1707: de 118 ejemplares censurados, 94 (79\%) lo han sido con base en el índice de ese año; 4 títulos están ya incluidos en el de 1584, 21 en el de 1612 , otros 29 en el de 1632 y 2 en el de 1640. 
El estudio de un caso como el de la Biblioteca de Navarra no permite concluir que estos retrasos en la aplicación de los expurgos fuese una práctica generalizada. No obstante, por lo señalado en la Biblioteca Histórica de Santa Cruz de Valladolid o en la Biblioteca del Colegio jesuita de Montilla (Sánchez, 2016, pp. 340-349) parece que se refrenda esta circunstancia. Las razones de este desfase cronológico son múltiples e interrelacionadas. Por un lado, la ingente tarea que suponía la aplicación de los cada vez más extensos índices inquisitoriales, comportó cierta incuria por parte de algunos censores. Por otro lado, el trasiego de ejemplares antes de recalar definitivamente en una biblioteca, sus procedencias anteriores, abría la posibilidad de no haber sido revisados en su momento. La oferta bibliográfica en las librerías incluía bastantes textos editados en tiempos pasados, muchos de los cuales procedían de almonedas. Conforme avanza en el siglo XVII, buena parte de los libreros infringirán el mandato inquisitorial de llevar un inventario y presentarlo a los representantes inquisitoriales, al igual que los calificadores y comisarios apenas realizarán visitas a librerías. Por lo que podían pasar varias décadas hasta que un libro incluido en un índice se expurgase.

Con independencia de que la obra expurgada ya estuviera recogida en índices anteriores, lo que a grosso modo sí se cumple, con excepciones, son los plazos estipulados para el expurgo tras la aparición de un nuevo índice. Hay que tener en cuenta que, en general, los índices acumulaban referencias, de modo que un libro presente en el índice de 1612, también aparecerá en el de 1707 . En un $43 \%$ de las anotaciones se detalla la fecha concreta del expurgo, y, en la mayoría de casos, este se efectuó el mismo año o en los años inmediatos a la aparición del índice mencionado.

\subsection{Modalidades de revisión y expurgo}

Cuando un libro era examinado y/o expurgado, el censor acostumbraba a dejar anotado en el ejemplar dicha revisión. Normalmente esa nota consta en la portada, en ocasiones en el verso de la misma, la primera hoja de los preliminares o en alguna hoja de guarda. Por lo general, presenta un modelo semejante: señala que el expurgo se efectúa conforme manda el Santo Oficio, indica el índice expurgatorio, la fecha y el lugar de su realización y, por último, la firma y rúbrica del censor. Dos ejemplos: en la portada del libro Primera parte de la Historia Pontifical y Católica de Gonzalo de Illescas (Madrid, 1652), se anota: «expurgado por comisión del santo officio de la Inquisición conforme al expurgatorio del año de 1707, por Fr. Jacinto de Leyzaur carmelita, Pamplona, año de $1708{ }^{14}$; en la hoja de guarda del libro De morte declamatio de Erasmo de Roterdam (Lyon, 1529), se asienta: "Yo el Maestro Fr. Marcos de Villalva, Abad de San Bernardo de Salamanca por comisión de los señores inquisidores de Valladolid hize expurgar este libro conforme al cathalogo nuevo [1584], fecha en Salamanca en 6 de abril de 1585, Fr. Marcos de Villalva (rubricado) ${ }^{15}$.

No obstante, en 29 ejemplares expurgados $(6 \%)$ no figura ninguna indicación. El ejemplar de la Silva de varia lecion de Pedro Mexía (Lyon, 1556), está expurgado sin

14 Sign. 109-5-4/56.

15 Sign. FA/76(2). 
nota alguna. También hay libros en los que falta alguno de estos elementos, los más frecuentes son el lugar y la fecha, y no siempre se registra el índice utilizado. Así, en 54 ejemplares $(9,8 \%)$ no consta la fecha del índice. Es el caso de Decretum Gratiani emendatum et notationibus..., comentado por Charles Du Moulin (Turín, 1588), en el que se anota: «Hago fee que este libro esta expurgado y para que conste ser verdad, lo firmé yo el comissario don Mateo Corella» ${ }^{16}$. En 127 ejemplares $(26 \%)$ tampoco aparece el nombre del censor. Aunque no es habitual, en algún ejemplar la anotación se completa con una frase aclaratoria. En el ejemplar De quatuor hominis novissimis liber de Dionysius Cartusianus (Lovaina, 1578), se lee: «Expurgado por orden del Santo Oficio según el expurgatorio del año 1640, y lo firmé yo, Don Jerónimo de Espoz y Zunzarren, Comissario del Santo Oficio. [En latín] Léase con cautela lo relacionado sobre el estado de las almas en el Purgatorio» ${ }^{17}$.

En seis libros, probablemente tras alguna denuncia o sospecha, la nota que certifica su revisión es para refrendar que no contiene nada censurable. Así, en la obra Elucidatorium ecclessiasticum... (París, 1556) de Clichtove se anota: "No es esta ediction la que contiene la improvaçión que este auctor hace de las palabras de la bendiçión del Cirio pasqual [...] que el expurgatorio del año 1640 manda se borre. Antes en esta ediçión se explica y modera el autor ${ }^{18}$.

A modo de advertencia, es usual la nota "auctor damnatus», "auctore damnato sed cum expurgatione permisso", escrita en las portadas junto al nombre de los autores, comentaristas, etc., catalogados de herejes. A veces también en páginas interiores, si el nombre del autor se repite. Las variantes textuales son diversas, desde escribirla de forma abreviada, solo las iniciales " $\mathrm{AD}$ ", hasta la tachadura del nombre junto a la nota. La mayoría de los libros que presentan esta nota, en mayor o menor grado, están expurgados, aunque también se localizan ejemplares con esta indicación y sin ninguna huella de expurgo. Un ejemplo es Concordantiae bibliorum utriusque testamenti... (Ginebra, 1555), realizado e impreso por Robert Estienne, que en la portada se anota "auctor damnatu permissum» y su interior está limpio de tachaduras. Otra advertencia, aunque menos frecuente, es la apostilla «caute lege» [leer con cautela], escrita en la portada de algunos ejemplares o en el margen de algún fragmento del texto.

En cuanto a las formas de expurgo se aplican varios métodos. La elección de uno u otro dependerá, sobre todo, de la porción de texto a eliminar o la gravedad de lo escrito, a veces también del nivel de pulcritud del censor. Tres son las principales modalidades: las tachaduras, cuya máxima expresión es el emborronamiento con tinta, las hojas mutiladas, cortadas o arrancadas y, en menor medida, la supresión de textos con papeles pegados sobrepuestos. Es habitual encontrar ejemplares donde se combinan varias de estas modalidades, incluso las tres. 
El método más común será la tachadura a tinta del texto, tanto en obras cuyo expurgo es mínimo, en las que solo se tachan palabras sueltas o frases, como el tachado de varios párrafos, líneas, columnas o páginas enteras, que es más frecuente. En un ejemplar de la obra Adversus omnes haereses libri XIIII de Alfonso de Castro (Amberes, 1565), solo se tachan dos alusiones a Tomas de Vio Cayetano; la Opera omnia quae ad criticam proprie spectant de Justus Lipsius (Amberes, 1600), aparece con páginas enteras tachadas; en la Práctica de curas y confessores de Benito Noydens (Madrid, 1688), presenta párrafos tachados. Dependiendo de la sensibilidad del censor, hay ejemplares expurgados de forma más radical, mediante el emborronado total de páginas o párrafos. Un ejemplo se observa en el ejemplar de la obra Postilla, hoc est, Enarratio Epistolarum et evangeliorum... de Georg Witzel (París, 1565) (fig. 2).

En el otro extremo, se localizan ejemplares en los que el texto a censurar, en lugar de tachado, aparece rayado o simplemente con una línea cruzada, lo que permite leer el contenido por completo. Las razones de estos simulacros de expurgo pueden ser diversas, desde no estar de acuerdo con dicho expurgo, hasta marcar el texto censurado a la espera de una intervención más detenida que nunca se producirá. Así, un ejemplar del Evangelium secundum Lucam enarrationum del franciscano Diego de Estella (Alcalá,

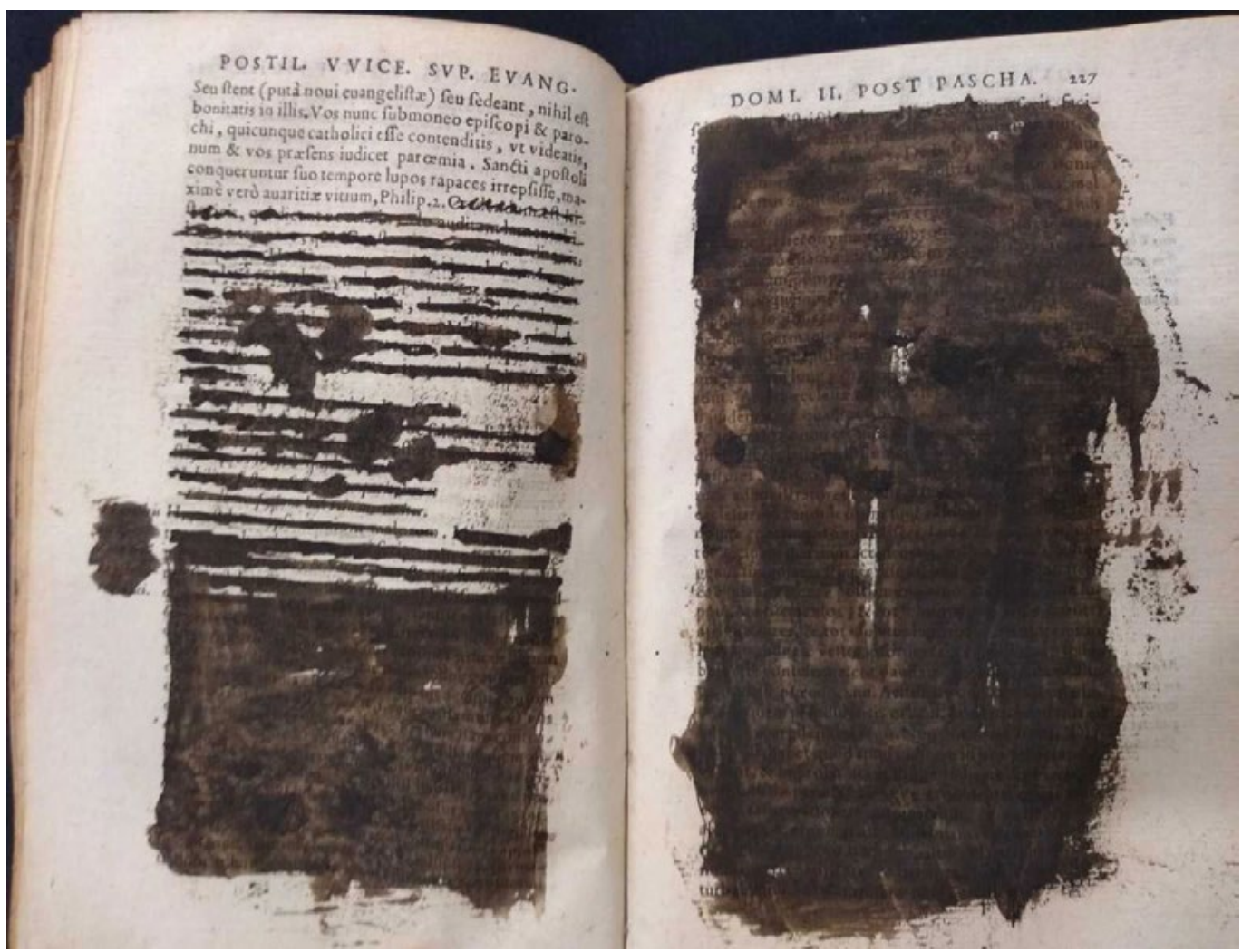

Figura 2. Georg Witzel, Postilla, hoc est, Enarratio Epistolarum et evangeliorum... (París, 1565), pp. 226-227. Sign. 109-9-1/119. 
1577-78), expurgado en 1586 por el también franciscano Fr. Tomás Martínez, prior del convento de Zaragoza, solo está levemente rayado pudiéndose leer su contenido. El texto censurado de un ejemplar del Promptuario espiritual de elogios de los santos de Fr. Ignacio Coutinho (Madrid, 1650), solo aparece con rayas verticales.

Otro método de expurgo más drástico y bastante utilizado son las hojas, fragmentos de hojas o cuadernillos enteros, cortados o arrancados. Se percibe con frecuencia en el expurgo de textos introductorios, dedicatorias u otros preliminares, escritos por autores de la primera clase. Personajes como Erasmo, Camerarius, Melanchthon, entre otros, están muy «castigados». Hay casos de mutilación impactantes, bien por su extensión o por su tosquedad. Al ejemplar De monetarum augmento variatione... (Turín, 1609), le amputaron 164 páginas seguidas (fig. 3) al Speculum astrologiae de Giuntini (Lyon, 1583), 30 páginas; los dos volúmenes del Nuevo aspecto de Theología Médico-Moral del cisterciense Antonio José Rodríguez (Zaragoza, 1742-1745) están totalmente descabalados. Las primeras hojas del ya mencionado Lucubrationes quotquot extant de Hilario de Poitiers (Basilea, 1550) aparecen recortadas de modo muy zafio (fig. 4).

La tercera modalidad es la supresión de texto mediante papeles pegados sobrepuestos. Generalmente son recortes de papel con adornos tipográficos o de hojas en blanco, siempre muy bien encoladas que impiden su despegue sin arriesgar la integridad de la hoja. Aunque el resultado es el mismo que los anteriores, es un método más respetuoso.

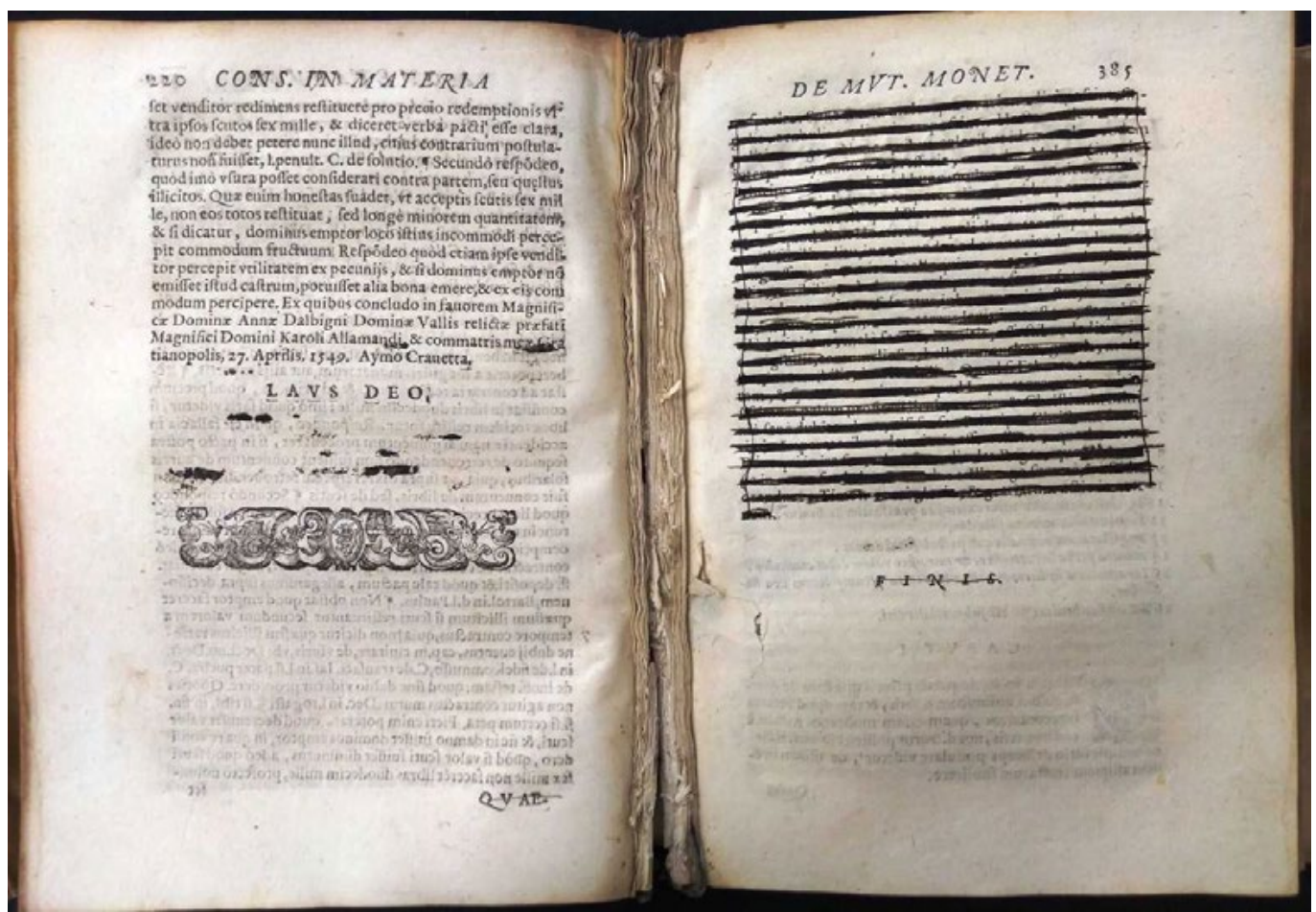

Figura 3. De monetarum augmento variatione, et diminutione tractatus varii (Turín, 1609), pp. 220, 385. Sign. 109-5-3/62. 


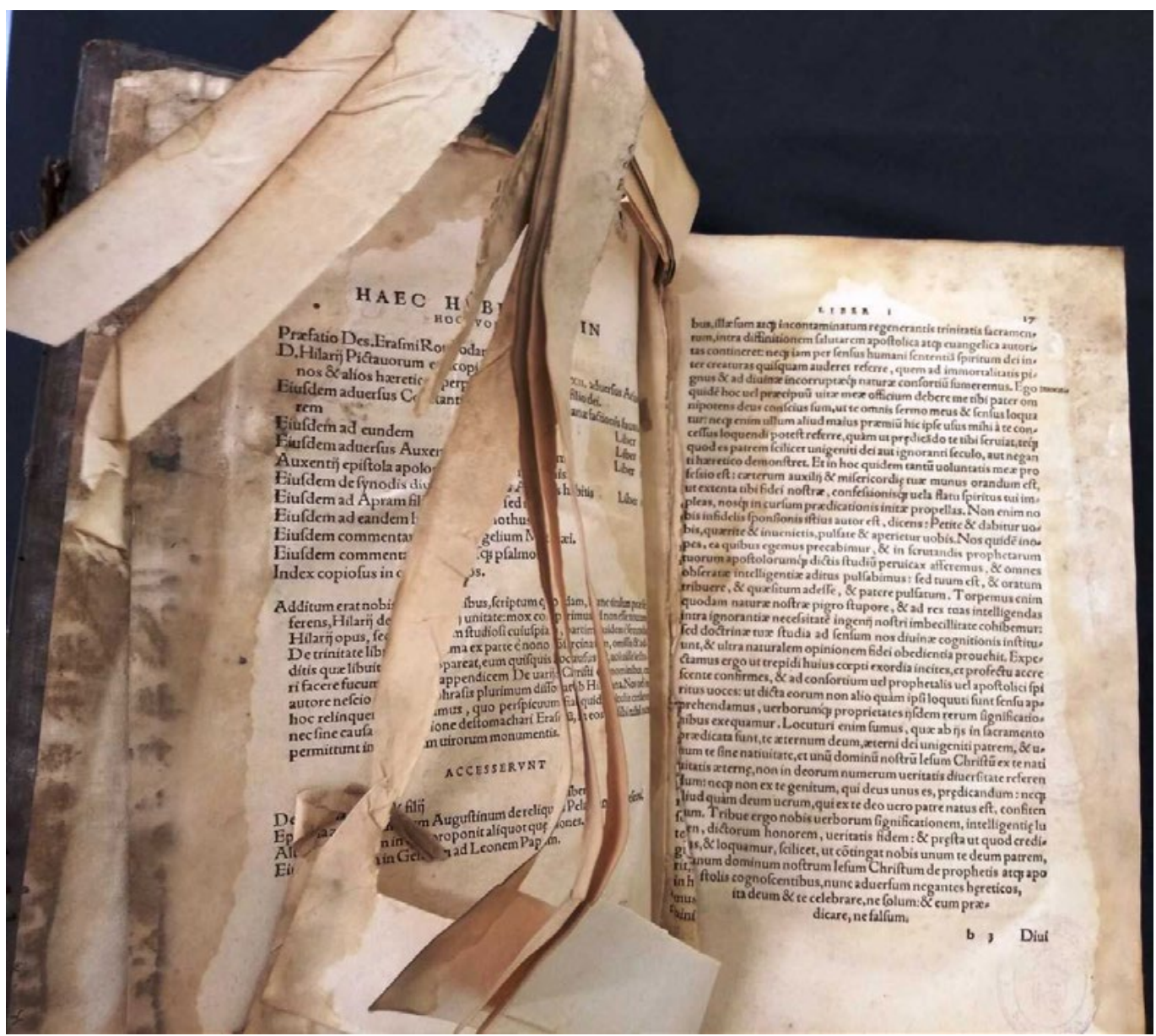

Figura 4. Hilario de Poitiers, Lucubrationes quotquot extant per Des. Erasmum Roterod. (Basilea, 1550). Sign. FAG/2689.

Entre los ejemplares expurgados con este método, destacan los tomos de la Americae Historia (Frankfurt, 1590-1605), con numerosos grabados de Theodor de Bry y textos de diversos autores. Procedente del monasterio de Fitero, el censor, Fr. Jacinto de Arellano, supo apreciar la calidad de las ilustraciones y expurgó el texto pegando papeles con cuidado de no estropear los grabados (fig. 5). Otros ejemplos: el libro Opus de emendatione temporum... de Scaliger (Leyden, 1598), Chronographiae libri quatuor de Genebrard (Lyon, 1609). En varios ejemplares, el expurgo se concreta pegando entre sí varias páginas yuxtapuestas del libro. Es el caso del Candelabrum aureum Eccles. Sanctae Dei... de Martín de Vivaldo (Venecia, 1600).

Una variedad muy poco común es la suplantación del texto censurado por otro texto impreso en el que se informa del expurgo. Lo encontramos en un ejemplar de la obra Eva y Ave o María triunfante de Antonio de Sousa Macedo (Madrid, 1731), cuya página 221 ha sido suplantada por otra impresa que indica que los párrafos que faltan los prohibió la Inquisición en 1736 (fig. 6). 


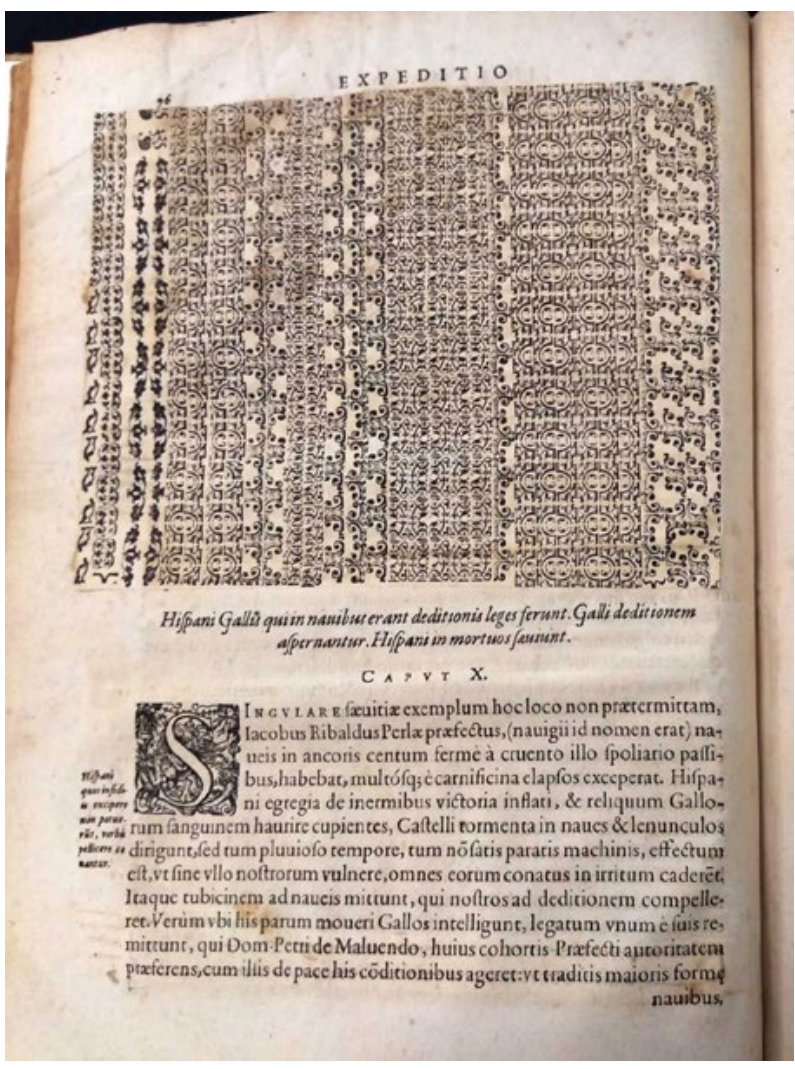

Figura 6. Antonio de Sousa Macedo, Eva y Ave o María triunfante (Madrid, 1731), p. 221. Sign. 109-5-4/43.
Figura 5. Girolamo Benzoni $\&$ Theodor Bry, Americae pars sexta sive Historiae... (Frankfurt, 1596), p. 96. Sign. 109-5-6/7(1).

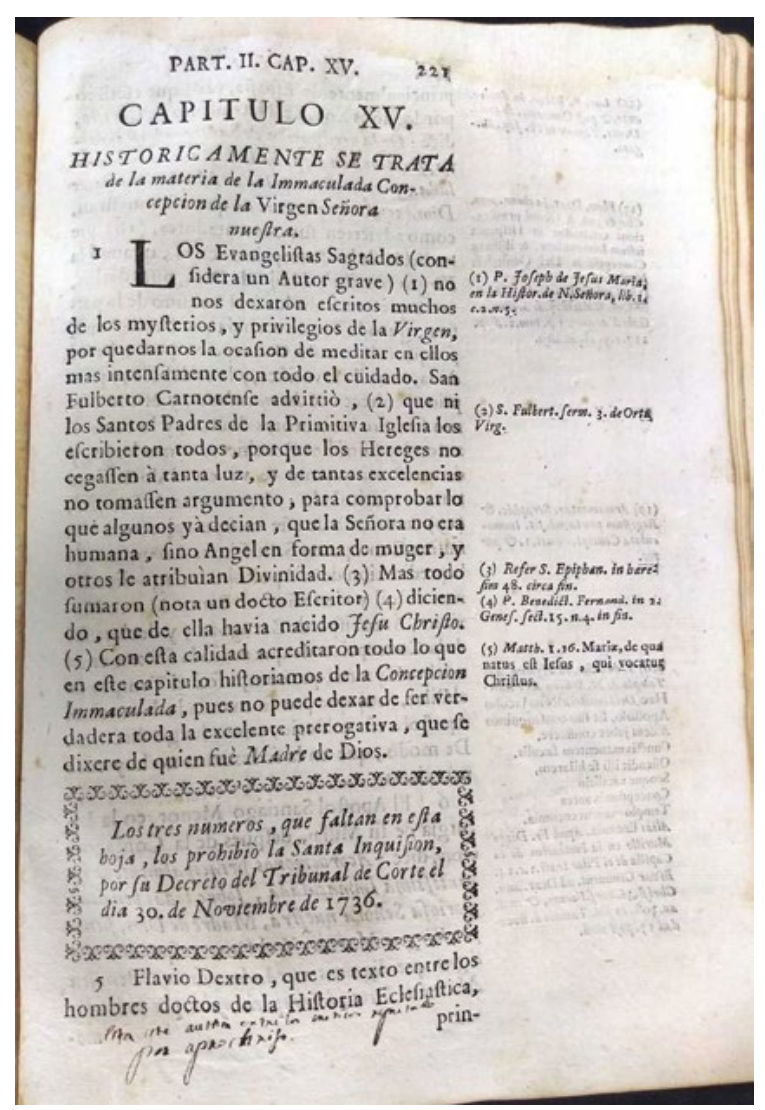




\subsection{Procedencia de los ejemplares expurgados}

Gracias a las marcas de propiedad -exlibris, supralibris- que aparecen en los ejemplares, así como a la información que aportan las anotaciones propias del expurgo -lugares y nombres de censores-, se ha podido determinar la procedencia de 314 ejemplares $(66 \%)$ ). Los 162 ejemplares sin especificar, probablemente se repartan entre todas las bibliotecas que se muestran, a excepción del monasterio de Fitero, pues los datos que ya presenta, no admiten muchos más ejemplares.

\section{Tabla 7. Procedencia}

Bibliotecas

Monasterio de Santa María la Real de Fitero (Cisterciense)

Convento de Santa Ana de Pamplona (Carmelitas Descalzos)

Convento de la Trinidad de Pamplona (Trinitarios Descalzos)

Convento de San Francisco - Pamplona / Olite (Franciscanos /

Franciscanos Conventuales)

Convento de Santiago Apóstol de Pamplona (Dominicos) 19

Convento del Carmen - Pamplona / Tudela (Carmelitas Calzados)

Colegio de la Anunciada (Jesuitas)

Convento de Santa Eulalia (Mercedarios)

Convento de Capuchinos - Pamplona / Tafalla

Monasterio de Santa María la Real de La Oliva (Cisterciense)

Convento de San Agustín de Pamplona (Agustinos Calzados)

Monasterio de San Salvador de Leire (Cisterciense)

Monasterio de Santa María de Iranzu (Cisterciense)

Monasterio de Santa María de Marcilla (Cisterciense)

Monasterio de San Salvador de Urdax (Premonstratense)

Biblioteca de D. Manuel de Lejalde

Fondo Sanz (San Martín de Unx)

Biblioteca de D. Lorenzo Lejalde

Biblioteca de D. José Zalba

Biblioteca de D. Mariano Arigita

Biblioteca de D. José Luis Ibarra

Nuevas adquisiciones Biblioteca de Navarra

Llama la atención el abultado número de ejemplares pertenecientes al monasterio de Fitero, cerca de un tercio del total. Varios factores explican este hecho. En primer lugar, la importancia de esta biblioteca, tanto en cantidad como en calidad de sus fondos. "La más completa de todas las del Císter navarro» (Ostolaza, 2018, pp. 143-152), como resultado de la acumulación de bibliotecas abaciales, especialmente de Fr. Marcos de

Ejemplares

(6)

$29 \quad 9,24$

$28 \quad 8,92$

$27 \quad 8,60$

$19 \quad 6,05$

$14 \quad 4,45$

$\begin{array}{ll}9 & 2,88\end{array}$

$6 \quad 1,92$

$5 \quad 1,60$

$4 \quad 1,28$

$3 \quad 0,96$

$1 \quad 0,31$

$1 \quad 0,31$

$1 \quad 0,31$

$1 \quad 0,31$

\begin{tabular}{l|r}
4 & \\
4 & \\
2 & \\
2 & 14 \\
1 & \\
1 & \\
\hline 4 & \\
\hline 314 & 1,45 \\
\hline
\end{tabular}


Villalba, Fr. Ignacio Fermín de Ibero y Fr. Plácido del Corral. Aunque, como el resto de bibliotecas conventuales, sufrió expolios durante los procesos desamortizadores, fue conservada con celo por el párroco de la localidad. Por otro lado, cada vez que se publicaba un nuevo índice inquisitorial, siempre se preocuparon por revisar sus libros. En 1707, solicitaban al tribunal de Logroño permiso y comisión para que el abad y dos o tres ayudantes pudieran expurgar los libros del monasterio, recordando las comisiones obtenidas para ello en 1633 y 1640 (Torres, 2002a, p. 165, n. 497). Además, había «cierta tradición» de cumplir escrupulosamente los mandatos inquisitoriales, quizá por la impronta del abad Ignacio de Ibero que había participado en la elaboración del índice de 1612.

A excepción del monasterio de Fitero, los demás datos son proporcionales al número de libros identificados procedentes de los conventos desamortizados. Apenas hay diferencias entre los ejemplares adscritos a los conventos de los carmelitas descalzos, trinitarios descalzos y a los de San Francisco de Pamplona y Olite. La testimonial presencia de libros de algunos monasterios -Leire, Iranzu, Marcilla, La Oliva, Urdax-, es previsible debido a los desastres que sufrieron durante la primera mitad del siglo XIX.

Junto a los ejemplares de estas bibliotecas eclesiásticas se localizan unos pocos libros expurgados procedentes de bibliotecas particulares como las ya mencionadas del jurista Manuel de Lejalde, de la familia Sanz de San Martín de Unx, y de José Zalba. A los que se añaden los del médico fiterano Lorenzo Lejalde (†1759), o los adquiridos en las últimas décadas por la Biblioteca de Navarra.

En relación a las procedencias, por los lugares y nombres de censores que aparecen en las notas de expurgo, se constata la movilidad de una parte considerable de los ejemplares. Alrededor del $34 \%$ de los que se conoce su procedencia, fueron expurgados fuera de conventos navarros. De ellos, el $11 \%$ en centros religiosos adscritos al distrito del tribunal de Logroño -Ágreda, Alfaro, Azpeitia, Bilbao, Calahorra, Durango, Fuenterrabía, Logroño, Oña, San Pedro Manrique, San Sebastián...-. Del 23 \% restante, el expurgo se realizó en localidades pertenecientes a otros tribunales de la Inquisición, entre los que destacan por este orden: Valladolid, Zaragoza y Toledo. Este trasiego de ejemplares tiene que ver con la movilidad de los religiosos y con la propia organización interna de las órdenes religiosas, que abarcaban amplios territorios sin ceñirse a las divisiones político-administrativas de los reinos de España. Algunos frailes, en los traslados a conventos navarros, llevaban consigo sus libros ya expurgados. Con el paso del tiempo esos libros acababan en los anaqueles de la biblioteca común. A modo de curiosidad, cabe señalar que tres libros fueron censurados en América, dos en México y uno en Nuevo México.

Varios ejemplares se expurgaron en las librerías, antes de su adquisición, durante las visitas que realizaban los calificadores. Del monasterio de Fitero procede una Biblia sacra de Vatablo (Salamanca, 1584), expurgada en Madrid conforme al índice de 1612 por el calificador y visitador de librerías, Fr. Gabriel González (Agulló, 1992, pp. 49, 272). También adquirida en Madrid es la obra completa de la Historiae animalium de Gesner (1617-1621), expurgada en 1646 conforme al índice de 1640 por Fr. Juan Ponce de León, también calificador y visitador de librerías (Agulló, 1992, pp. 49-50). Otros 
dos censores aparecen vinculados a Madrid: Pedro López de Montoya y Fr. Francisco de Jesús (Jódar), ambos calificadores de la Suprema y partícipes en las labores de elaboración de los índices de 1583-1584 y 1612-1614 respectivamente.

\subsection{Los censores: calificadores, comisarios y comisionados}

El $67 \%$ de los libros expurgados -320 ejemplares-, lleva la firma del censor. En total son 155 firmas, de los que se han identificado 148 nombres. De estos nombres reconocidos, en 95 casos $(64 \%)$, su firma solo consta en un ejemplar, por el contrario, la firma de 8 censores $(5 \%)$ aparece en 10 o más libros. Los ya mencionados Fr. Jacinto de Arellano y Fr. Joaquín Salvador, del monasterio de Fitero, son los que más se prodigan, -en 45 y 34 ejemplares-, a los que le sigue el comisario y vicario de Cintruénigo, Sebastián Gallardo, cuya firma se halla en 19 ejemplares expurgados conforme al índice de 1640. También superan la decena los ejemplares expurgados por los comisarios, Jerónimo de Espoz y Zunzarren (índice de 1640) y Juan de Ciriza, canónigo de la catedral de Pamplona (índices 1612, 1640), así como por el trinitario Fr. Juan de la Anunciación (índice 1707), el cisterciense Fr. Benito López, abad de Fitero, y el dominico Fr. Gonzalo de Arriaga, prior del convento de Santiago de Pamplona, calificador del tribunal de Logroño y posteriormente de la Suprema (índices 1632, 1640).

En cuanto a su procedencia, 77 de ellos $(52 \%)$ pertenecen al área jurisdiccional del tribunal de Logroño, de los que 56 (38\%) son navarros o su actividad censora se desarrolla en Navarra. La mayoría en Pamplona (29), por las razones ya expuestas destacan también los censores del monasterio de Fitero (12), el resto se reparten: Tudela (4), La Oliva-Carcastillo (3), Olite (2), Estella (2), Corella (2), uno en Cintruénigo y Elizondo-Urdax. A ellos se suman 5 censores de localidades guipuzcoanas integradas en el obispado de Pamplona: 3 de San Sebastián, uno de Fuenterrabía y otro de Azpeitia.

En el conjunto de los libros expurgados intervienen las tres figuras de censores señaladas: calificadores, comisarios y comisionados.

Tabla 8. Censores

\begin{tabular}{lcc} 
Censores & Total & \% \\
Calificadores & 36 & 24,32 \\
\hline Comisarios & 42 & 28,38 \\
\hline Comisionados & 56 & 37,84 \\
\hline Sin especificar & 14 & 9,46 \\
\hline \multicolumn{1}{c}{ Total } & 148 & 100,00 \\
\hline
\end{tabular}

De 134 censores se conoce su modo de vinculación con la Inquisición. Los datos confirman lo expuesto por la historiografía inquisitorial. Son los comisionados -clérigos regulares cualificados- de los propios conventos quienes tienen mayor presencia en los expurgos; suponen algo más del $37 \%$, frente a los que ostentan algún título inquisitorial, sea de calificador $(24 \%)$ o de comisario $(28 \%)$. 
Tabla 9. Cronología censores

\begin{tabular}{|c|c|c|c|c|c|}
\hline Siglos & Calificadores & Comisarios & Comisionados & Total & $\%$ \\
\hline XVI & 4 & 9 & 2 & 15 & 11,20 \\
\hline XVII & 20 & 23 & 33 & 76 & 56,72 \\
\hline XVIII & 12 & 10 & 21 & 43 & 32,08 \\
\hline Total & 36 & 42 & 56 & 134 & 100,00 \\
\hline
\end{tabular}

Por siglos, se constata una tendencia al alza del número de comisarios y calificadores en los años circundantes a la publicación de los sucesivos índices, que alcanzan su punto más álgido en las décadas centrales del siglo XVII. Sin embargo, a partir del índice de 1612, ante el aumento de obras a revisar, serán las personas no vinculadas directamente con el Santo Oficio quienes adquieran cada vez mayor protagonismo. Por otro lado, en consonancia con el paulatino declive de la actividad inquisitorial conforme avanza el siglo XVIII, disminuye considerablemente el número de comisarios y calificadores y, aunque también se reduce la cifra de comisionados conventuales, su contribución en los expurgos seguirá siendo superior. Si bien su actividad se centra en torno al índice de 1707, pues los pocos libros expurgados en la segunda mitad del siglo XVIII, llevan la firma de un comisario o calificador.

Tabla 10. Censores: clero regular y secular

\begin{tabular}{lrrrrrrr}
\multicolumn{1}{c}{ Censores } & Clero regular & \multicolumn{1}{c}{$\%$} & Clero secular & $\%$ & Laicos & $\%$ & Total \\
Calificadores & 30 & 83,34 & 5 & 13,89 & 1 & 2,77 & 36 \\
\hline Comisarios & 4 & 9,52 & 38 & 90,48 & & & 42 \\
\hline Comisionados & 52 & 92,86 & 4 & 7,14 & & & 56 \\
\hline Sin especificar & 6 & 42,86 & 8 & 57,14 & & & 14 \\
\hline \multicolumn{1}{c}{ Total } & 92 & 62,16 & 55 & 37,16 & 1 & 0,68 & 148 \\
\hline
\end{tabular}

En la relación de censores, excepto un laico, el jurista Agustín de Morlanes, consultor del tribunal de Zaragoza, el resto son eclesiásticos. Predomina el clero regular $(62 \%)$ sobre el secular (37\%). Más del $83 \%$ de los calificadores pertenecen a alguna orden religiosa, por el contrario, la gran mayoría (90\%) de los comisarios pertenecen al clero secular, bien canónigos ${ }^{19}$, párrocos o presbíteros beneficiados.

Dentro del clero regular, con independencia de su vinculación directa o no con la Inquisición, más de la mitad $(51 \%)$ de los que se conoce su trayectoria vital, ocuparon cargos relevantes en la jerarquía de sus congregaciones. Se localizan 14 abades, 17 priores, 11 provinciales y 5 rectores de colegios. El resto, cuando menos, fueron lectores o maestros de teología.

19 En rigor, los canónigos no forman parte del clero secular diocesano, los de la diócesis de Pamplona seguían la regla de san Agustín. Pero tampoco forman parte del clero regular en la medida que están vinculados a un lugar -catedral o colegiata- determinado. Además, están vinculados a los obispos, como asesores y consejeros. 
Tabla 11. Censores según órdenes religiosas

\begin{tabular}{lcc} 
Orden religiosa & Núm. de censores & $\%$ \\
\hline Cistercienses & 16 & 17,40 \\
\hline Franciscanos & 15 & 16,35 \\
\hline Dominicos & 15 & 16,35 \\
\hline Jesuitas & 9 & 9,89 \\
\hline Capuchinos & 5 & 5,54 \\
\hline Carmelitas Observantes & 5 & 5,54 \\
\hline Jerónimos & 4 & 4,43 \\
\hline Benedictinos & 4 & 4,43 \\
\hline Carmelitas Descalzos & 3 & 3,28 \\
\hline Trinitarios Descalzos & 3 & 3,28 \\
\hline Mínimos & 1 & 1,08 \\
\hline Premonstratenses & 1 & 1,08 \\
\hline Agustinos Calzados & 1 & 1,08 \\
\hline Sin especificar & 10 & 10,27 \\
\hline & 92 & 100,00 \\
\hline
\end{tabular}

En la distribución por órdenes religiosas, con la excepción de los cistercienses de Fitero que distorsionan los datos, a los que se suman los nombres de otros de monjes cistercienses $^{20}$, se confirma la tendencia generalizada a nivel nacional. Están presentes las principales órdenes, predominando los dominicos y franciscanos y, en menor medida, los jesuitas. Un $33 \%$ eran o llegarían a ser calificadores del Santo Oficio, de los que once lo fueron de la Suprema: los cistercienses Fr. Ignacio de Ibero y Fr. Saturnino Arriaga, los dominicos Fr. Pedro Venero, Fr. Gonzalo de Arriaga, Fr. Miguel Escolano y Fr. José Poveda, el jesuita Andrés Mendo, el trinitario Fr. Juan de Cantabrana, el carmelita Fr. Francisco de Jesús (Jódar), el capuchino Fr. Bernardo de Pamplona y Fr. Juan Ponce de León de la orden de los Mínimos. Dos llegaron a ser inquisidores: los dominicos Fr. José Poveda, que formó parte de la Suprema en las postrimerías del siglo XVIII, y Miguel Escolano, del tribunal de Zaragoza durante la segunda mitad del siglo XVIII, así también Fr. Nicolás Ricardi, que años después será censor de la Congregación del Índice de Roma. Otros alcanzarán la mitra episcopal: Fr. Luis Díez de Armendáriz, Fr. Ignacio de Santibáñez, Fr. José Vicente Díaz Bravo. Algunos calificadores también ejercieron responsabilidades como visitadores de librerías. Además de los ya citados, el capuchino Fr. Miguel de Cepeda, el jerónimo Fr. Pedro Reinoso y el dominico Fr. Pedro Venero. Este último también participó en la elaboración del índice de 1640. Entre los visitadores

20 Del monasterio de Fitero, además de los ya citados: Fr. Nicolás de Ardanaz, Fr. Saturnino de Arriaga, Fr. Plácido del Corral, Fr. Atanasio Cucho, Fr. Blas Díez y Torres, Fr. Manuel Lasso de Castilla, Fr. Benito López, Fr. Marcelo de Murillo. Del monasterio de La Oliva surgen las firmas de Fr. Luis Díez de Armendáriz, Fr. Manuel de Cerededa y Fr. Esteban de Labraza. Mientras que el expurgo del único ejemplar procedente del monasterio de Leire, un sermonario de Antonio Vieira, María, Rosa Mystica (Madrid, 1688), está firmado en 1712 por el abad Fr. Matías de Salinas. 
nombrados por el tribunal de Logroño se ha de señalar a Fr. Blas Díez, abad de Fitero (1796-1800) y al carmelita Fr. Jacinto de Leyzaur, revisor de las librerías pamplonesas durante las primeras décadas del siglo XVIII (Torres, 2006, p. 385).

Al menos cuatro ejercieron de comisarios en algún tribunal inquisitorial de distrito. Norberto de Escorz, premonstratense del monasterio de Urdax y vicario de la parroquial de Elizondo, en 1627 fue nombrado comisario para la zona fronteriza de Baztan (Contreras \& Cristóbal, 1994, p. 86). En el otro extremo del dominio español, el franciscano Fr. Juan de Góngora en 1631 era comisario en Nuevo México.

La formación académica e intelectual de la mayoría de los censores del clero regular era superior a la del secular. Un número significativo de los que aparecen en la nómina también fueron escritores y/o requeridos para emitir aprobaciones en publicaciones de otros autores. La lista es amplia, algunos ya han sido aludidos -Andrés Mendo, Gonzalo de Arriaga, Ignacio de Ibero, Miguel de Cepeda, Díaz Bravo, etc.-. De los no mencionados: Fr. Luis Vallejo, teólogo dominico y prior de la provincia de Santiago de Nueva España; los jesuitas Andrés Cabezudo, rector del colegio de Logroño (1735) y Francisco Maldonado, catedrático en la Universidad de Salamanca; el jerónimo Fr. Lucas de Alaejos, bibliotecario y prior del monasterio de San Lorenzo de El Escorial; el franciscano Fr. Alonso Vélez de Ontanilla, el benedictino Gaspar de Avilés, etc. Entre los navarros o residentes en Navarra destacan: el trinitario descalzo Fr. Juan de Jesús María, natural de Mañeru, que llegó a ser definidor general de la Orden en España; el carmelita Fr. José Urtesabel $^{21}$, doctor en teología del convento de Pamplona; el franciscano Fr. Esteban de Fresneña; el jesuita Pedro Francisco de Inurre, vicerrector del colegio de la Anunciada de Pamplona.

En cuanto al clero secular, de los 55 censores identificados, al menos el $78 \%$ ocuparon cargos inquisitoriales, bien como comisarios (38) o calificadores (5). Ya se ha señalado que ambas funciones no conllevaban salario, por lo que estos eclesiásticos disponían de sus propias ocupaciones e ingresos.

Tabla 12. Censores. Clero secular

\begin{tabular}{lcc} 
Censores & Total & $\%$ \\
Canónigos & 17 & 30,91 \\
\hline Párrocos & 15 & 27,28 \\
\hline Presbíteros & 13 & 23,64 \\
\hline Otros & 2 & 3,63 \\
\hline Sin especificar & 8 & 14,54 \\
\hline \multicolumn{1}{c}{ Total } & 55 & 100,00 \\
\hline
\end{tabular}

21 Curiosamente, su obra Primera y segunda parte del Septenario angélico... (Pamplona, 1734-1738) fue prohibida en el índice de 1747. 
Predominan los canónigos ( $31 \%$ ), en su mayoría catedralicios, si bien la suma de los clérigos diocesanos -vicarios parroquiales y presbíteros beneficiados-constituye más de la mitad del total, a los que se añade un capellán real y comisario de Corte, Juan de Llano (1586), y un fiscal del tribunal de la Inquisición de México, el riojano Diego Mangado y Clavijo (1740).

Aunque en general su formación no es tan lustrosa como la del clero regular, prácticamente todos los canónigos y una parte relevante del resto son doctores o licenciados en teología o derecho. En algunos casos el cargo inquisitorial facilitará sus carreras eclesiásticas. Tres canónigos llegarán a ser obispos: Martín Garnica, calificador del tribunal de Toledo (1589), canónigo de Cuenca (1592) y obispo de Osma (1594); Martín de Axpe y Sierra, canónigo de Burgos (1580), comisario del tribunal de Valladolid (1585) y obispo de Palencia (1596); y el pamplonés Juan Ramón Santos de Larumbe, canónigo de Pamplona (1798), comisario del tribunal de Logroño (1804) y obispo de Tudela (1817). Unos pocos promocionarán dentro de la organización inquisitorial: el canónigo de Calahorra Prudencio Carrión, será consultor del tribunal de Logroño y colaborará con la Suprema en los trabajos del índice de 1612; Juan de Layda Villaviciosa, comisario de mar en Pasajes y San Sebastián, en 1636 es comisario de Corte, en 1638 notario del secreto en el tribunal de Logroño. Fernando de Arnedo, canónigo de la Colegiata de Berlanga de Duero, alcanzará un puesto de notario y tesorero en el tribunal de Cuenca (1626); Pedro de Aguirre, comisario de Bilbao y notario en el tribunal de Logroño (1583); Pedro Fernández de Arguedas, presbítero beneficiado de Ágreda y Ablitas, comisario de aduanas en Ágreda (1593) y tesorero del tribunal de Murcia (1601).

Respecto a censores navarros, en su mayoría con el título de comisarios, además de los ya citados, destacan los canónigos de la catedral de Pamplona, Miguel Alcoz y Torres, cuya firma aparece en 7 libros expurgados (índice 1584) y Francisco Cruzat, canónigo desde 1638 (índice 1640). Miguel Domingo de Irigoyen y Elizondo, chantre de la iglesia colegial de Tudela (índice 1632) y Miguel Ibáñez, también canónigo tudelano desde 1604 (índice 1612). Entre los párrocos de la diócesis de Pamplona se ha de mencionar al vicario de san Pedro de Estella, Juan Vélaz de Medrano, y al rector de la parroquial de Azpeitia, Francisco de Celayarán, cuyos nombres se muestran respectivamente en 8 libros expurgados (índice 1640). Del siglo XVIII, los pamploneses Joaquín Francisco de Mina, vicario de la parroquia de San Nicolás y José Ignacio de Labari, vicario de la parroquia de San Lorenzo y posteriormente de la de San Juan. Juan López de Burgoa, vicario de la parroquia de San Vicente de San Sebastián y juez eclesiástico (índice 1640). Los corellanos Andrés de Olando (índice 1612) y Mateo Corella y Fernández (índice 1640), vicarios de la parroquia del Rosario en dicha localidad. En cuanto a los presbíteros destacan Justo Pastor de Laurendi, que también ejerció de abogado y su firma se encuentra en 7 libros (índice 1790 y posteriores edictos). José de Mendinueta, beneficiado en la parroquial de Fuenterrabía y notario del tribunal de Logroño en dicha villa (índice 1707). Juan Esteban de Elgueta, beneficiado de Olite y Pitillas (índice 1640); Martín de Ilarregui, de la parroquia de san Pedro de Estella (índice 1707); por último, Félix Lobera, presbítero tudelano con título de calificador del tribunal de Logroño (edicto 1793). 


\section{EJEMPLARES NO EXPURGADOS}

Al cruzar los datos del catálogo de la Biblioteca con las más de ocho mil referencias del índice acumulativo de libros prohibidos y expurgados que recoge Martínez de Bujanda, descubrimos ejemplares que, según los índices inquisitoriales, deberían estar expurgados, pero nunca fueron revisados.

\subsection{Autores, obras y ejemplares}

Se han identificado 92 ejemplares, que se corresponden con 73 títulos en 84 ediciones, pertenecientes a 62 autores, más 3 obras colectivas. De más de la mitad de las obras (43 títulos, $59 \%$ ), se descubren tanto ejemplares expurgados como sin expurgar; los hay de una misma edición y de distintas ediciones. De la Primera parte de los tratados sobre los evangelios... de López de Andrade (Madrid, 1622), hay un ejemplar expurgado y otro sin expurgar; al igual que del Libri decem Hypotyposeon theologicarum... de Martínez de Cantalapiedra (Salamanca, 1582), o de la obra colectiva Ecclesiasticae historiae autores (Basilea, 1554), en un ejemplar están tachados los nombres de los autores herejes Musculus y Camerarius con la anotación de «auctor damnatus», mientras que el otro ejemplar está totalmente limpio. Ejemplos de mismas obras en distintas ediciones: Elegantiarum latinae linguae libri sex de Lorenzo Valla, con dos ejemplares editados en Lyon, uno en 1556 que está expurgado y otro en 1545 sin expurgar; de la Política para corregidores y señores de vassallos... de Jerónimo Castillo de Bobadilla se dispone de dos ejemplares, uno expurgado (Barcelona, 1616) y el otro sin censurar (Madrid, 1597).

Del resto de títulos sin expurgar $(41 \%)$, la Biblioteca posee un ejemplar. Así, Della fabrica del mondo de Alunno (Venecia, 1600), Canones Concilii Provincialis Coloniensis anno celebrati MDXXXVI (Lyon, 1544), Tratado del vino aguado y agua envinada, de Jerónimo Pardo (Valladolid, 1661), Discursos predicables sobre los Evangelios de Diego Murillo (Lisboa, 1602), etc.

Tabla 13. Clases de autores

\begin{tabular}{ccc} 
Clases & Autores & $\%$ \\
\hline $1^{\text {a }}$ clase & 7 & 10,77 \\
\hline $2^{\text {a }}$ clase & 55 & 84,61 \\
\hline $3^{\text {a }}$ clase & 3 & 4,62 \\
\hline Total & 65 & 100,00 \\
\hline
\end{tabular}

Predominan de forma notoria $(84 \%)$ los autores católicos. En la mayoría de los casos, el texto a censurar indicado en los índices es mínimo: unas palabras, una o dos frases, un párrafo. Por ejemplo, una frase en El fénix y su historia natural de Pellicer de Ossau (Madrid, 1630), un párrafo en el Theatro del mundo y de el tiempo de Gallucci (Granada, 1606). No obstante, existen unas pocas obras en los que el expurgo ordenado es mayor. Así, en el tomo quinto de los Discursos elocuentes... de Francisco Ignacio 
de Porres (Alcalá, 1644) son tres páginas seguidas las que censura el índice de 1707, o la obra In universam sacerdotiorum... de Jean Coras (Toulouse, 1687), está salpicada de numerosas frases censuradas por el mismo índice.

Pese a ser minoritario el dato, es más llamativo que no se expurgaran algunos ejemplares de obras cuyos autores, comentaristas o editores están catalogados como herejes. Es el caso del calvinista Alsted y su Encyclopaedia (Herborn, 1630), del Tractatus juridico-politico-polemico-historicus... del jurista alemán Klock (Núremberg, 1651), de la Practica medicinae generalis del médico suizo Wecker (Lyon, 1606), o de la Moralia de Plutarco (Frankfurt, 1580), en el que debería estar expurgado la dedicatoria del editor Feyerabend.

\subsection{Cronología y lugares de impresión}

Si se compara proporcionalmente con los porcentajes cronológicos de los libros expurgados, en este caso, con ser importante las obras del siglo XVI, predominan las editadas en el siglo XVII y aumentan las del siglo XVIII.

Tabla 14. Cronología

\begin{tabular}{|c|c|c|c|c|}
\hline Siglos & Núm. obras (ediciones) & $\%$ & Núm. obras (ejemplares) & $\%$ \\
\hline XVI & 30 & 35,72 & 30 & 32,61 \\
\hline XVII & 41 & 48,81 & 47 & 51,09 \\
\hline XVIII & 13 & 15,47 & 15 & 16,30 \\
\hline Total & 84 & 100,00 & 92 & 100,00 \\
\hline
\end{tabular}

$\mathrm{Al}$ establecer la relación entre estos títulos y su inclusión en los índices inquisitoriales, casi la mitad de los mismos (48\%) fueron incorporados en los índices del siglo XVIII. Teniendo en cuenta que la mayor parte de estos autores y títulos no son considerados "peligrosos», el mínimo expurgo a realizar, así como el paulatino debilitamiento del control inquisitorial, no sorprende que estas obras estuvieran sin examinar. De hecho, ejemplares de estas u otras obras de características similares localizados en bibliotecas digitales españolas tampoco están expurgados.

Al ser la mayor parte de los ejemplares no expurgados obras de autores católicos, tampoco sorprende que sean España y Francia los principales lugares de edición. Un $76 \%$ de este conjunto se editaron entre ambos países, siendo España el de superior porcentaje $(41 \%)$. Por supuesto, las pocas obras en las que intervienen autores heréticos son ediciones alemanas o suizas. Por ciudades, al igual que entre los libros expurgados, la más frecuente es Lyon, sobre todo en las ediciones del siglo XVI, así como Madrid en las ediciones del siglo XVII.

\subsection{Materias y temas}

En lo que respecta a las materias comprendidas, salvando las proporciones, mantienen la misma tendencia que el conjunto de ejemplares expurgados. 
Tabla 15. Materias

\begin{tabular}{|c|c|c|}
\hline Materias & Títulos & $\%$ \\
\hline Religión & 51 & 69,86 \\
\hline Derecho & 8 & 10,96 \\
\hline Ciencias & 4 & 5,48 \\
\hline Historia & 4 & 5,48 \\
\hline Filología/Literatura & 3 & 4,11 \\
\hline Filosofía & 1 & 1,37 \\
\hline Política & 1 & 1,37 \\
\hline Otros & 1 & 1,37 \\
\hline & 73 & 100,00 \\
\hline
\end{tabular}

Es evidente que son las obras de temática religiosa las que se imponen $(69,8 \%)$, incluso con un porcentaje superior al de los expurgados. El dato es razonable por la procedencia del fondo, así como por la condición de la mayoría de los autores. Entre los temas religiosos destacan las obras relacionadas con la teología (18 títulos), la oratoria sacra (13) y, en menor medida, los comentarios bíblicos (10). Excepto dos, los libros jurídicos se refieren a temas de derecho canónico, mientras que los históricos a la antigüedad clásica romana. En cuanto a los científicos, además de los ya citados, destacan dos ediciones del Examen de ingenios de Huarte de San Juan impresas en Leyden en 1591 y 1603, que toman como modelo la edición de Bilbao de 1580, incluida en el índice de 1612.

\subsection{Procedencia}

Es en la procedencia de estos ejemplares no expurgados donde más varían los datos con respecto a los expurgados. El porcentaje de los que se desconoce su origen es el doble, constituyen algo más de dos tercios del total. Es de suponer que, al igual que los expurgados, la mayoría provenga de fondos conventuales.

Tabla 16. Procedencia

\begin{tabular}{|c|c|c|}
\hline Bibliotecas & Ejemplares & $\%$ \\
\hline Sin adscripción & 62 & 67,40 \\
\hline Convento de Santa Ana de Pamplona (Carmelitas Descalzos) & 8 & 8,70 \\
\hline Convento de la Trinidad de Pamplona (Trinitarios Descalzos) & 5 & 5,44 \\
\hline Convento del Carmen - Pamplona / Tudela (Carmelitas Calzados) & 4 & 4,35 \\
\hline Biblioteca de D. Manuel de Lejalde & 4 & 4,35 \\
\hline Fondo Sanz (San Martín de Unx) & 3 & 3,26 \\
\hline Convento de Santiago Apóstol de Pamplona (Dominicos) & 2 & 2,17 \\
\hline Nuevas adquisiciones Biblioteca de Navarra & 2 & 2,17 \\
\hline Convento de Capuchinos - Pamplona / Tafalla & 1 & 1,08 \\
\hline Biblioteca de D. José Zalba & 1 & 1,08 \\
\hline Total & 92 & 100,00 \\
\hline
\end{tabular}


De los pocos que se sabe su filiación, tienen más peso relativo los procedentes de bibliotecas particulares, del jurista Lejalde y de la familia de médicos Sanz, ambas formadas durante el último tercio del siglo XVIII y principios del XIX. Los procedentes de centros religiosos mantienen una relación proporcional con el conjunto del fondo desamortizado. Así, destacan los ejemplares de los carmelitas descalzos y trinitarios. No debe extrañar que ningún ejemplar de los identificados proceda del monasterio de Fitero, como se ha señalado, aquí la revisión de libros se llevó con gran escrupulosidad.

Una de las razones que se podría esgrimir para explicar la existencia de ejemplares sin expurgar pudiera ser la ocultación de los mismos ante los censores. Sin embargo, al analizar los autores y obras, así como sus cronologías, no parece que este sea un argumento viable. Ya se ha señalado que en su mayoría no son libros que comprometan la ortodoxia católica. Por otro lado, la mitad de los mismos aparece en los índices inquisitoriales del siglo XVIII $(1707,1747)$, cuando el control del Santo Oficio ya no era tan férreo. Es más factible atribuir la falta de expurgo a cierta desidia o desinformación por parte de los comisarios o comisionados conventuales. También pudiera ser consecuencia de la movilidad de algunos ejemplares, que acabaron engrosando los fondos de estas bibliotecas, a través donaciones o adquisiciones, sin haber sido expurgados.

\section{LIBROS PROHIBIDOS}

$\mathrm{Al}$ igual que se constata la presencia de libros que pasaron desapercibidos al expurgo, también se descubren en la Biblioteca de Navarra unos pocos libros prohibidos por la Inquisición. En este apartado, sin menoscabo de los libros heredados de la desamortización, cobran mayor protagonismo las colecciones particulares recibidas, así como las adquisiciones efectuadas por la Biblioteca.

\subsection{Autores, obras y ejemplares}

Se han identificado un total de 48 ejemplares, que se corresponden con 47 obras de 42 autores, más 4 anónimas. De estos autores, 9 (19\%) están catalogados de primera clase, esto es, heréticos. Entre ellos, Joannes Baptista Piscator y la obra Epitome omnium operum divi Aurelii Augustini... (Colonia, 1549), François Hotman, Protestation et defense pour le Roy de Navarre Henry III... contre l'iniuste tyranique Bulle de Sixte V (s. 1., 1587), Bartholomaeus Scultetus, Gnomonice de Solariis (Görlitz, 1572), o Richard Montagu, Analecta ecclesiasticarum exercitationum (Londres, 1622). Habría que añadir otros autores, no heréticos en sentido estricto, como los jansenistas Edmond Richer y su libro Libellus de Ecclesiastica et politica potestate (Colonia, 1701) o François-Phillipe Mésenguy, Abbrégé de l'histoire de l'Ancien Testament (París, 1757), ambas prohibidas en el índice de 1747. Así como al ensayista ateo Holbach y su obra La moral universal... (Madrid, 1812), prohibida mediante un edicto de 1819.

La mayoría de las obras prohibidas corresponde a autores católicos, la más conocida es la Historia del famoso predicador fray Gerundio de Campazas, del jesuita José Fran- 
cisco de Isla (Madrid, 1758), prohibida en 1760 e incluida en el índice de 1790. Otras obras: Origen y continuación del instituto y religión geronimiana, de Fr. Hermenegildo de San Pablo (Madrid, 1669), prohibida por un edicto en 1689 e incluida en el índice de 1707; Thesauri conceptionis Immaculatae Virginis Mariae... pars prima, de Sánchez Zarzosa (Antequera, 1631) (índice 1640); Anales de Aragón desde el año 1540... hasta el año 1558, de Panzano (Zaragoza, 1705) (índice 1707); Vasconiana ou Recueil des bons mots... et des recontres les plus vives des Gascons editado por M. Brunet (París, 1710), prohibida por un edicto de 1789.

A modo de curiosidad, afloran 5 obras prohibidas en las que figura Pamplona en el pie de imprenta. Las obras Phisonomía y varios secretos de naturaleza de Jerónimo Cortés (Pamplona, s. a.), y Conversaciones instructivas entre... Fray Bertoldo... y don Terencio de Fr. Francisco de Los Arcos (Pamplona, 1786). A estas dos se añaden tres más cuyos pies de imprenta son falsos. Dos obras satíricas: La dispute d'un asne contre frere Anselme Turmeda (Pampelune, 1606), que llevaba prohibida desde el índice de 1583 (Itúrbide, 2015, p. 161), y el opúsculo del siglo XVIII, Virtud al uso y mystica a la moda (Pamplona, s. a.). La tercera, titulada Espejo de la philosophia y compendio de toda la medicina, de Juan de la Torre y Valcárcel (Pamplona, 1715)22, nos pone en relación con una variante en la dinámica censoria de la Inquisición. Como se ha señalado, ante el aluvión de obras a examinar, en 1614 se introdujo la prohibición temporal de ciertas obras hasta su expurgo. En la práctica, esta prohibición provisional se tornó definitiva, ya que en su mayor parte nunca fueron revisadas (Pardo, 1991, p. 122). Este es el caso de la obra de Torre y Valcárcel, que se prohíbe en el índice de 1747 hasta que se expurgue. Lo mismo ocurre con la Catedra de la Cruz de Mateo de la Natividad (Valladolid, 1639), prohibida hasta su expurgo (índice de 1707).

\subsection{Cronología, inclusión en los índices y lugares de impresión}

Desde el punto de vista cronológico hay un cambio sustancial en comparación tanto con los libros expurgados, como con los no expurgados.

Tabla 17. Cronología

\begin{tabular}{|c|c|c|}
\hline Siglos & Núm. obras & $\%$ \\
\hline XVI & 5 & 10,63 \\
\hline XVII & 13 & 27,66 \\
\hline XVIII & 18 & 38,30 \\
\hline XIX & 11 & 23,41 \\
\hline Total & 47 & 100,00 \\
\hline
\end{tabular}

22 La identificación de los elementos decorativos que incluye (capitulares y adornos tipográficos) la vinculan a Madrid, al taller de Antonio González Reyes o sus herederos. 
Mientras que entre los expurgados destacan los editados en el siglo XVI y son escasos los del siglo XVIII y, en los no expurgados dominan los del siglo XVII, en el pequeño grupo de libros prohibidos prevalecen los editados en el siglo XVIII. Este porcentaje aumenta considerablemente si sumamos los publicados en las primeras décadas del siglo XIX. Es más, casi la mitad, 23 títulos (49\%), se concentra en el último tercio del siglo XVIII y principios del siglo XIX. Si bien, se ha de tener en cuenta las 18 obras (38\%) editadas en los siglos XVI y XVII, puesto que es el período de mayor control inquisitorial. En este último dato quizá algo tenga que ver las licencias especiales que otorgaba la Inquisición a ciertas personas para leer y poseer libros prohibidos.

En consonancia con la cronología de las distintas ediciones, están su incorporación a los índices o edictos de libros prohibidos.

Tabla 18. Inclusión en los Índices

\begin{tabular}{|c|c|c|}
\hline Índices & Libros & $\%$ \\
\hline 1583 & 2 & 4,25 \\
\hline 1612 & 2 & 4,25 \\
\hline 1632 & 4 & 8,51 \\
\hline 1640 & 2 & 4,25 \\
\hline 1707 & 8 & 17,03 \\
\hline 1747 & 5 & 10,64 \\
\hline 1790 & 8 & 17,03 \\
\hline Supl. 1805 & 6 & 12,76 \\
\hline Edictos hasta 1819 & 10 & 21,28 \\
\hline Total & 47 & 100,00 \\
\hline
\end{tabular}

Se evidencia cómo de la mitad de los mismos $(51 \%)$ son prohibidos a partir de la última década del siglo XVIII, cuando el control inquisitorial está agonizando. Mientras que los incluidos en el índice de 1707, excepto la obra de Panzano, son obras editadas en la segunda mitad del siglo XVII.

Al detallar este reducido número de libros prohibidos por países y ciudades de publicación, no sorprende que sean España, Francia y Alemania, por ese orden, los principales países, así como Madrid y París las ciudades que sobresalen. Cronológicamente los publicados en España, excepto del siglo XVI que no hay ninguno, se distribuyen de forma equilibrada, 8 son del siglo XVIII (Madrid, Pamplona, Zaragoza), 6 del siglo XIX (Madrid y Cádiz) y 5 del siglo XVII (Madrid, Valencia y Antequera). De las 11 ediciones francesas predominan las del siglo XVIII (6 títulos). Las obras de autores heréticos están editadas en Alemania en los siglos XVI y XVII, a excepción de 2 que están publicadas en Londres en el siglo XVII, la mencionada de Montagu y la Historia del Concilio Tridentino de Paolo Sarpi (Londres, 1619). 


\subsection{Materias y temas}

En lo referente a los contenidos, aunque prevalecen los de temática religiosa, los porcentajes de asuntos profanos adquieren en proporción mayor notoriedad que en los libros expurgados, incluso la suma de todos ellos supera a los religiosos.

Tabla 19. Materias

\begin{tabular}{|c|c|c|}
\hline Materias & Obras & $\%$ \\
\hline Religión & 20 & 42,55 \\
\hline Política & 10 & 21,29 \\
\hline Filología/Literatura & 6 & 12,76 \\
\hline Ciencias & 3 & 6,39 \\
\hline Derecho & 2 & 4,25 \\
\hline Filosofía & 2 & 4,25 \\
\hline Usos y costumbres - España & 2 & 4,25 \\
\hline Historia & 1 & 2,13 \\
\hline Otros & 1 & 2,13 \\
\hline Total & 47 & 100,00 \\
\hline
\end{tabular}

Entre los primeros, además de las obras teológicas, destacan las relacionadas con la historia eclesiástica. Un dato de interés es que la mayoría están editadas en los siglos XVII y XVIII, no hay ninguna obra de las primeras décadas del siglo XIX. Todo lo contrario que los títulos prohibidos de contenido político, que se concentran, -8 de los 10-, en los primeros años del siglo XIX. Siendo el Santo Oficio un baluarte fundamental en la defensa del Antiguo Régimen, estos libros fueron objeto de condena por su crítica al estado absolutista y al poder de la Iglesia. Dos son los principales temas que surgen: las relaciones Iglesia y Estado y la defensa de las ideas liberales. Es el caso de la Teoría de las Cortes... de Francisco Martínez Marina (Madrid, 1813), o la obra anónima titulada Abusos introducidos en la disciplina de la Iglesia... (Madrid, 1813), ambas condenadas por un edicto de 1815; Sucesos memorables de Maximiliano Robespierre (S. 1., 1804), vedada en 1806 aun para los que tenían licencia para poseer libros prohibidos; Del origen de la potestad temporal de los Papas de François Sabbathier (Madrid, 1789), prohibida en 1817.

En cuanto a la literatura satírica, además de los ya citados, destaca el poema épico Gli animali parlanti de Giambattista Casti (Ámsterdam, 1804), prohibido también para los que tenían licencia. Así como la obra filológica Thesaurus philologicus seu Clavis Scripturae de un autor condenado, Johann Hottinger (Zúrich, 1659). Por último, señalar dos obras relacionadas con la visión crítica que se tenía en el extranjero de las costumbres españolas: Voyage en Espagne del marqués de Langle (París, 1796) y Tableau de l'Espagne moderne de Jean François Bourgoing (París, 1807). 


\subsection{Procedencia}

A la hora de analizar su procedencia, dos datos marcan la relación o inconexión con el control inquisitorial. Por un lado, el elevado porcentaje de ejemplares en los que no se ha podido determinar su adscripción $(43 \%)$, por otro, la importancia de las adquisiciones realizadas por la propia Biblioteca (33\%).

\section{Tabla 20. Procedencia}

\begin{tabular}{|c|c|c|}
\hline Bibliotecas & Ejemplares & $\%$ \\
\hline Sin adscripción & 21 & 43,75 \\
\hline Nuevas adquisiciones Biblioteca de Navarra & 16 & 33,33 \\
\hline Convento de la Trinidad de Pamplona (Trinitarios Descalzos) & 3 & 6,25 \\
\hline Biblioteca de D. José Goya y Muniáin & 2 & 4,17 \\
\hline Fondo Sanz (San Martín de Unx) & 2 & 4,17 \\
\hline Biblioteca de D. Manuel de Lejalde & 1 & 2,08 \\
\hline Convento de Santa Ana de Pamplona (Carmelitas Descalzos) & 1 & 2,08 \\
\hline Otras entidades públicas & 2 & 4,17 \\
\hline & 48 & 100,00 \\
\hline
\end{tabular}

Si bien no hay una prueba fehaciente, es de suponer que la mayoría de los 21 títulos que se desconoce su origen provengan de los fondos desamortizados, pues casi todos son de temática religiosa y se corresponden con las ediciones más antiguas. A los que se suman, los tres identificados de los trinitarios y el ejemplar procedente de los carmelitas descalzos. Aunque pudiera ser que hubieran pasado desapercibidos a la censura inquisitorial, una explicación más plausible es que formaran parte de las autorizaciones temporales concedidas por el inquisidor general a personas relevantes de los centros religiosos -priores, maestros y lectores de teología, colaboradores del Santo Oficio, etc.-, a fin de poder disponer de algunos libros prohibidos necesarios para sus actividades. Estas licencias se debieron de otorgar con relativa frecuencia, pues muchos conventos habilitaban un espacio exclusivo para guardar bajo llave los libros prohibidos (Suboh, 2018, pp. 9-10). Un buen ejemplo es el volumen considerable de estos libros hallados en 1767, tras la expulsión de los jesuitas, en los aposentos del rector del colegio de Pamplona, Ignacio Iriarte (Vergara, 2006, pp. 325-328).

Por otro lado, destaca la presencia de 5 ejemplares $(10 \%)$ procedentes de colecciones particulares. Dos de ellos llevan el exlibris del canónigo y bibliotecario José Goya y Muniáin: el tomo primero de una edición en francés de la publicación periódica inglesa Le spectateur ou Le Socrate moderne (Ámsterdam, 1716) y De episcopis eorumque iuribus, privilegiis... del calvinista Kaspar Ziegler (Núremberg, 1689). Del jurista Manuel de Lejalde, el Tractatus nomico-politicus de contributionibus de Kaspar Klock (Frankfurt, 1656), autor del que se localiza otro libro entre los no expurgados, también de la biblioteca de Lejalde. Es probable que ambos poseedores, siendo personajes de prestigio social, tuvieran licencia del Santo Oficio para tener libros prohibidos. 
Por último, un tercio de los libros prohibidos proceden de adquisiciones realizadas por la Biblioteca, durante la segunda mitad del siglo XX y primeros años del presente siglo. En cierto modo, este dato distorsiona lo expuesto sobre la huella de la Inquisición en la Biblioteca de Navarra, puesto que, en algunos casos, proceden de colecciones bibliográficas extranjeras, fuera del alcance del Santo Oficio. Sin embargo, no dejan de ser obras prohibidas por esta institución y por tanto deben ser mencionadas. La mayoría de ellos -11 de los 16 títulos- fueron editados en las postrimerías del siglo XVIII y primeros años del XIX. Forman parte de la política de adquisiciones desarrollada en las décadas centrales del siglo XX ya comentada. Casi todos ellos han sido aludidos en páginas anteriores; por señalar alguno más: Examen de los delitos de infidelidad a la patria, del afrancesado Félix Reinoso (Auch, 1816), o el Dictamen de D. Joaquín Lorenzo Villanueva... acerca... del proyecto de decreto sobre los tribunales protectores de la religión (México, 1813).

\section{CONSIDERACIONES FINALES}

La presencia de la Inquisición en el fondo antiguo de la Biblioteca de Navarra permite estudiar con un ejemplo la incidencia de la acción y control ideológico que esta institución ejerció a lo largo de la Edad Moderna. Sirve como fuente documental en la medida que reúne un contingente de libros procedentes de importantes bibliotecas conventuales navarras desamortizadas. El análisis cuantitativo realizado ofrece datos significativos.

Se constata la existencia de obras relacionadas con el Santo Oficio que muestran la conexión de algunos lectores con la actividad inquisitorial. No solo se localizan la mayor parte de los índices de libros prohibidos y expurgados, sino también otros libros que tratan de los métodos inquisitoriales y de su autoridad.

La máxima expresión de la actividad inquisitorial la aportan los libros expurgados. Aunque el 3,7\% del total del fondo antiguo (476 ejemplares) pueda parecer exiguo, no lo es si se considera la procedencia eclesiástica del mismo. Aunque predominan los autores y obras del ámbito católico, es considerable el número de autores catalogados como herejes o sospechosos de herejía. En ocasiones los ejemplares fueron revisados dos o más veces a medida que aparecían nuevos índices.

Los libros expurgados se concentran entre el siglo XVI y primera mitad del siglo XVII, y descienden abruptamente en el siglo XVIII. Esta característica se ajusta a lo que asevera la historiografía sobre el devenir del Santo Oficio.

Para la Inquisición era evidente que la herejía venía del extranjero, por lo que no extraña que sean las obras editadas en Francia (Lyon y París), principal país exportador de libros a España, las que ofrecen el mayor porcentaje de libros expurgados. Si bien, en términos absolutos, los libros editados en España ocupan un lugar destacado, en el conjunto del fondo antiguo, el número de los expurgados es reducido. En ello juega un papel importante la censura previa establecida (aprobaciones y licencias), así como la autocensura de los propios autores, temerosos de que sus obras tuvieran problemas con el Santo Oficio. 
En cuanto a autores no católicos, libros científicos, obras patrísticas o de clásicos grecolatinos, además de Francia, predominan las ediciones alemanas (Frankfurt) y suizas (Basilea) del siglo XVI.

Desde el punto de vista temático predominan de forma notable los libros religiosos en este orden: teología, exégesis bíblica, oratoria sacra y patrística. A gran distancia se sitúan el resto de materias: derecho, historia, ciencias, filología y literatura clásica y son escasos los de contenidos filosóficos y políticos. Dentro de las pocas obras científicas, la medicina ocupa un lugar destacado, seguida de los temas de astronomía y astrología.

Son los índices de 1640 y 1707 los más mencionados en las anotaciones de expurgo, en muchos casos la única que aparece con independencia del importante porcentaje de títulos incorporados en índices anteriores. Al desfase cronológico entre la publicación de una obra y su inclusión en los índices, se añade este retraso en la acción real del expurgo, todo ello menoscaba la eficacia inquisitorial.

Tres son los habituales modos de expurgo: las tachaduras, las hojas mutiladas o arrancadas y la supresión de textos con papeles sobrepuestos. Es habitual encontrar ejemplares donde se combinan varias de estas modalidades.

Se ha podido determinar la procedencia del $66 \%$ de los ejemplares expurgados. Destaca el elevado número de los provenientes del monasterio de Fitero, cerca de un tercio del total, lo que induce a pensar que en dicho monasterio fueron muy cuidadosos con el cumplimiento de los mandatos inquisitoriales. En cuanto al resto, los datos son proporcionales al número de libros identificados procedentes de los conventos desamortizados. También se localizan unos pocos libros de bibliotecas particulares.

Destaca la movilidad de una parte considerable de los ejemplares, ya que un tercio de los mismo fue expurgado fuera de Navarra, antes de recalar en algún convento navarro.

En cuanto a los censores, los datos obtenidos confirman lo expuesto por la historiografía inquisitorial. Más que los calificadores o comisarios, son los comisionados de los propios conventos quienes tienen mayor presencia en los expurgos. En conjunto predomina el clero regular sobre el secular, sobre todo entre los que ostentan el título de calificador, si bien el cargo de comisario está casi monopolizado por el clero secular. Dentro del clero regular, más de la mitad de los censores ocupó cargos relevantes en sus congregaciones, algunos también en la organización del Santo Oficio e incluso en la jerarquía eclesiástica. Entre el clero secular destacan los canónigos, aunque la suma de los clérigos diocesanos -vicarios parroquiales y presbíteros-sobrepasan la mitad.

Por otro lado, se constata la existencia de libros que, pese a estar incluidos en los índices, pasaron desapercibidos para los censores. Así como obras y ediciones con varios ejemplares, en los que unos fueron expurgados y otros no. En su mayoría no son libros que comprometan la ortodoxia católica y, en general, el texto a censurar es mínimo. No obstante, entre ellos hay obras de autores considerados herejes. En este grupo de ejemplares no expurgados, con ser importante las obras del siglo XVI, prevalecen las 
editadas en el siglo XVII y aumentan las del siglo XVIII. La mitad de las mismas aparecen en los índices inquisitoriales del siglo XVIII, cuando el control del Santo Oficio ya no es tan férreo. De este conjunto de libros no expurgados, el porcentaje de los que se desconoce su procedencia constituyen algo más de dos tercios del total. Es de suponer que provengan también de los fondos conventuales. Sin embargo, de los pocos que se conoce su filiación, tienen más peso relativo los procedentes de bibliotecas particulares.

También se ha comprobado la presencia de unos pocos libros prohibidos. La mayoría de estas obras son de autores católicos, aunque también hay algunos catalogados como heréticos. Desde el punto de vista cronológico, hay un cambio sustancial en comparación con los libros expurgados. En este pequeño grupo prevalecen los editados en las últimas décadas del siglo XVIII y primeras del XIX, cuando la Inquisición está en su fase terminal. En lo referente a los contenidos, aunque dominan las materias religiosas, los temas profanos adquieren mayor notoriedad, en especial los de contenido político. En concreto los que atacan los pilares del Antiguo Régimen: el estado absolutista, el poder de la Iglesia y la sociedad estamental. De los que se conoce su procedencia cobran mayor protagonismo las colecciones particulares recibidas, así como las adquisiciones realizadas por la Biblioteca.

En definitiva, con el presente trabajo, de índole cuantitativo, se ha pretendido abrir una línea de investigación sobre la presencia de la Inquisición en el reino de Navarra, desde el siglo XVI hasta los inicios del XIX, a través de su huella censoria reflejada en las publicaciones utilizadas, principalmente, por las comunidades religiosas.

\section{LISTA DE REFERENCIAS}

Agulló y Cobo, M. (1992). La imprenta y el comercio de libros en Madrid: siglos XVI-XVIII. Madrid: Universidad Complutense.

Barberá Matías, B. (2014). Censura y expurgo en los incunables de la Biblioteca Histórica de la Universidad de Valencia. Scripta: revista internacional de literatura $i$ cultura medieval i moderna, 4, 40-67. Doi: https://doi.org/10.7203/ scripta.4.4125

Bombín Pérez, A. (1997). La Inquisición en el País Vasco: el tribunal de Logroño (15701610). Bilbao: Universidad del País Vasco.

Collantes de Terán, M. ${ }^{a}$. J. (2001). Censura inquisitorial y devociones populares en el siglo XVIII. Revista de la Inquisición, 10, 75-164.

Contreras Contreras, J. \& Cristóbal Martín, M. ${ }^{a}$. A. (1994). Logroño y el Santo Oficio del Reino de Navarra. En J. L. Gómez Urdáñez (ed.), Historia de la ciudad de Logroño. III, Edad Moderna (pp. 71-92). Logroño: Ayuntamiento: Ibercaja.

Defourneaux, M. (1973). Inquisición y censura de libros en la España del siglo XVIII. Madrid: Taurus.

Elizari Huarte, J. F. (2000). La Biblioteca de Navarra. Boletín de la ANABAD, 3-4, 349-367. 
Galende Díaz, J. C. \& Santiago Medina, B. (2007). Las visitas de navíos durante los siglos XVI y XVII: historia y documentación de una práctica inquisitorial. Documenta \& Instrumenta, 5, 51-76.

Galindo Azkunaga, A. E. (2015). Libros expurgados de la Biblioteca Histórica de Santa Cruz de Valladolid. Valladolid: Universidad.

García Aguilar, M. ${ }^{a}$. I. (2019). Perseguir la herejía: libros prohibidos en el Colegio de la Santa Cruz de Querétaro. Revista Complutense de Historia de América, 45, 113-132. Doi: https://doi.org/10.5209/rcha.64689

García-Molina Riquelme, A. M. (2006). La Inquisición y la gran biblioteca de Guardias Marinas. En E. Gacto Fernández (coord.), Inquisición y censura: el acoso a la inteligencia en España (pp. 77-87). Barcelona: Dykinson.

Guibovich Pérez, P. M. (2001). Custodios de la ortodoxia: los calificadores de la Inquisición de Lima, 1570-1754. Revista de la Inquisición, 10, 213-229.

Itúrbide Díaz, J. (2015.). Los libros de un Reino: historia de la edición en Navarra (1490-1841). Pamplona: Gobierno de Navarra. Anexo: CD-ROM, Diccionario de impresores y libreros en Navarra.

Iturriaga Elorza, J. (1992). Las censuras inquisitoriales a libros del siglo XV y XVI actualmente en la Biblioteca del Santuario de Loyola. Memoria ecclesiae, 3, 159-178.

Kamen, H. (1988). La Inquisición española. Nueva edición totalmente reescrita y puesta al día (3. ${ }^{\mathrm{a}}$ ed). Barcelona: Crítica.

Leoz Floristán, C. (2005). El Excmo. Sr. Don Miguel Sanz y Lafuente. Pamplona: Analecta.

López Vela, R. (1986). El calificador en el procedimiento y la organización del Santo Oficio. Inquisición y órdenes religiosas en el siglo XVII. En J. A. Escudero López (coord.), Perfiles jurídicos de la Inquisición española (pp. 345-390). Madrid: Universidad Complutense.

Luzuriaga Sánchez, G. (2008). Las huellas de la Inquisición en la Biblioteca de la Universidad de Oñati. Boletín de la Real Sociedad Bascongada de Amigos del País, 64, 2, 751-765.

Martínez de Bujanda, J. (2016). El índice de libros prohibidos y expurgados de la Inquisición española (1551-1819): evolución y contenido. Madrid: Biblioteca de Autores Cristianos.

Muñoz Sempere, D. (2008). La Inquisición española como tema literario: política, historia y ficción en la crisis del Antiguo Régimen. Suffolk: Támesis.

Navarro Loidi, J. (2017). El expurgo de la Biblioteca del Real Colegio de Caballeros Cadetes de Artillería de Segovia: nuevos datos. Llull: revista de la Sociedad Española de Historia de las Ciencias y de las Técnicas, 84, 157-176.

Ostolaza Elizondo, M. ${ }^{a}$. I. (2018). La memoria de los libros: las bibliotecas del Císter navarro hasta la desamortización. Pamplona: Universidad Pública de $\mathrm{Na}$ varra.

Panizo Santos, I. (2000) Inventario de la antigua Biblioteca de Navarra (1842-1936), Madrid: el Autor [CD-ROM].

Pardo Tomás, J. (1991). Ciencia y censura: la inquisición española y los libros científicos en los siglos XVI y XVII. Madrid: Consejo Superior de Investigaciones Científicas. 
Pardo Tomás, J. (2003). Censura inquisitorial y lectura de libros científicos. Tiempos modernos: revista electrónica de Historia Moderna, 9, 1-16

Peña Díaz, M. (2004). El libro bajo sospecha (siglos XVI-XVII). En P. M. Cátedra (coord.), La memoria de los libros: estudios sobre la historia del escrito $y$ de la lectura en Europa y América (vol. 1, pp. 805-824). Salamanca: Instituto de Historia del Libro y la Lectura.

Peña Díaz, M. (2015). Escribir y prohibir: Inquisición y censura en los Siglos de Oro. Madrid: Cátedra.

Pérez, J. (2002). Crónica de la Inquisición en España. Madrid: Martínez Roca.

Pinto Crespo, V. (1983). Inquisición y control ideológico en la España del siglo XVI. Madrid: Taurus.

Pinto Crespo, V. (1989). Pensamiento, vida intelectual y censura en la España de los siglos XVI y XVII. Edad de oro, 8, 181-192.

Reguera Acedo, I. (1984). La Inquisición española en el País Vasco: el Tribunal de Calahorra, 1513-1570. San Sebastián: Txertoa.

Reyes Gómez, F. de los (2000). El libro en España y América: legislación y censura (siglos XV-XVIII) (2 vols.). Madrid: Arco Libros.

Sánchez Herrador, M. A. (2016). La Biblioteca del Colegio de La Encarnación de los jesuitas de Montilla. Córdoba: Universidad.

Suboh Jarabo, Y. (2018). La censura y control inquisitorial en 1747 y las obras de literatura espiritual y religiosa de la España del siglo XVII. Anuario del Centro de Estudios Históricos "Prof. Carlos S. A. Segreti», 18, 1-21.

Torres Arce, M. (2002a). Un tribunal de la fe en el reinado de Felipe V: reos, delitos y procesos en el Santo Oficio de Logroño (1700-1746). Logroño: Instituto de Estudios Riojanos.

Torres Arce, M. (2002b). La inquisición en Navarra al final del Antiguo Régimen, ¿la hora Navarra? En J. Bravo (ed.), Espacios de poder: Cortes, ciudades y villas (S. XVI-XVIII) (vol. 2, pp. 465-498). Madrid: Universidad Autónoma.

Torres Arce, M. (2006). Inquisición, regalismo y reformismo borbónico: el tribunal de la Inquisición de Logroño a finales del Antiguo Régimen. Santander: Universidad de Cantabria.

Vergara Ciordia, J. (2006). Inventario de los libros prohibidos del colegio de los jesuitas de Pamplona en tiempos de su expulsión. En Navarra. Memoria e imagen: actas del VI Congreso de Historia de Navarra (vol. 2, pp. 323-336). Pamplona: Eunate. 